SANTOS T., NUNES L., FARIA P. (2017), Production of eco-efficient earth-based plasters: influence of composition on physical performance and bio-susceptibility. J. Cleaner Production 167, 55-67.

https://doi.org/10.1016/j.jclepro.2017.08.131

\title{
Production of eco-efficient earth-based plasters: influence of composition on physical
} performance and bio-susceptibility

Tânia Santos ${ }^{\mathrm{a}}$, Lina Nunes ${ }^{\mathrm{b}}$, Paulina Faria ${ }^{\mathrm{c}^{*}}$

a. CERIS - Civil Engineering Research and Innovation for Sustainability and Universidade NOVA de Lisboa, Department of Civil Engineering, 2829-516 Caparica, Portugal, tr.santos@campus.fct.unl.pt

b. LNEC, Structures Department, Av. do Brasil, 101, 1700-066 Lisbon and cE3c - Centre for Ecology, Evolution and Environmental Changes / Azorean Biodiversity Group, Universidade dos Açores, 9700-042, Angra do Heroísmo, Açores, Portugal, linanunes@lnec.pt

c. CERIS - Civil Engineering Research and Innovation for Sustainability and Universidade NOVA de Lisboa, Department of Civil Engineering, 2829-516 Caparica, Portugal, paulina.faria@fct.unl.pt (* - corresponding author)

\begin{abstract}
An experimental campaign was developed to evaluate the properties of earth plastering mortars, not only at the level of workability and physic-mechanical performance but also their susceptibility for biological colonization. A ready-mixed earth mortar and several other mortars formulated with a raw clayish earth were produced. The influence of partial replacement of fine sand by a phase change material (PCM) and the addition of low amounts of oat fibres and hydrated air lime were assessed. The experimental campaign shows that the PCM completely changes the mortar workability, with a decrease on wet density. The addition of PCM and fibres decreases the bulk density and, consequently, increases the porosity of the mortars. The presence of PCM, fibres and air lime decreases the thermal conductivity. Earth mortars are susceptible to mould
\end{abstract}


development, and the fibres or PCM seem to intensify their bio-susceptibility. A low addition of air lime increases $\mathrm{pH}$ and inhibits fungal growth though decreasing the mechanical properties. Mortars with PCM, fibres and air lime present a higher surface roughness in comparison to other mortars, including the ready-mixed earth mortar with fibres. Surface roughness was found to be an important factor influencing the level of colonization.

\section{Keywords}

Earth plastering mortar; air lime; natural fibre; phase change material; physical property; biosusceptibility

\section{Introduction}

Earth is, together with wood, one of the oldest building materials known to man. After decades of neglect, the use of earth is regaining importance as a building material and an example are earthbased plasters that are now recognized, produced and applied as highly eco-efficient (Darling et al., 2012; Emiroğlu et al. 2015; Liuzi and Stefanizzi, 2016; Maddison et al., 2009). Nevertheless, research is needed to improve and optimize these plasters.

Currently, these plasters are made of clayish mortars without any or, at least, without high amounts of binders, like lime or cement (Eires et al., 2017; Gomes et al., 2016; Niroumand et al., 2017). Thus, in comparison to common plasters, the stone mining, transport and energy consumption for the production of earth-based plasters is very low. When comparing, by life cycle assessment (LCA) methodology, environmental impacts of earthen plasters with plasters based on conventional binders, Mèlia et al. (2014) showed that the first outperform all the others.

Earth plastering mortars, as other building products based on raw clay, have a high capacity to adsorb and desorb water vapour (Lima et al., 2016). Therefore, they can strongly contribute to regulate the relative humidity of the indoor air (Cagnon et al., 2014; Emiroğlu et al. 2015; Liuzzi and Stefanizzi, 2016; Randazzo et al., 2016), improving indoor air quality and inhabitants comfort and health (Lima et al., 2016), but also improving energy performance of the whole building 
(McGregor et al., 2014). Aesthetic, like natural colouring from the clay and texture, are also recognized as important aspects that can be explored.

The technical characteristics and efficiency of these mortars only recently gain the interest of the scientific community and begin to be methodically tested (Delinière et al., 2014; Hamard et al., 2013; Stazi et al., 2016). However, there are few earth building standards that can be applied and, therefore, even testing needs to be studied and defined. Limiting the development of unwanted biological growth is one important aspect to study.

Generally, an earth mortar is composed by a clayish earth and, depending on the earth composition, additional sand is frequently added to reduce the clay content. Natural fibres may be included to reduce linear drying shrinkage, dry bulk density and thermal conductivity (LaborelPréneron et al., 2016), while promoting the adhesion strength of plasters to the walls (Lima and Faria, 2016) and, eventually and in certain contents, increasing the compressive strength (Palumbo et al., 2016). For an improved performance, innovative materials may be added to achieve certain characteristics. For instance, phase change material (PCM) may be added to increase thermal efficiency (Baetens et al., 2010) but this must be done without compromising the general characteristics of mortars, in fresh and hardened state. The amount of water and moisture inside buildings are key factors in triggering the strong growth of fungi in building materials, which can affect the health of the occupants, causing respiratory problems, and causing colour change and deterioration of building materials (Huang et al., 2015).

Biological deterioration by moulds can occur on plasters made with any type of binder if used without additional biocides or protected by an adequate coating (Huang et al., 2015). Certain added materials, application technologies and environmental conditions may increase the deterioration level. The two most relevant environmental factors for biological development are moisture and temperature (Röhlen, 2012; Viitanen et al., 2010). High relative humidity allows the proliferation and growth of microorganisms and the presence of extreme temperature values hinders their development; the average room temperatures are adequate to biological growth 
(Viitanen et al., 2010). Linked to these environmental factors, intrinsic characteristics of the mortars, like $\mathrm{pH}$, porosity and chemical composition, as a potential supply of nutrients, can also play an important role on microbial proliferation (Lin et al., 2017; Nielsen et al., 2004; Verdier et al. 2014). High relative humidity increases the concentration and diversity of microorganisms on surfaces damaged by water (Lin et al., 2017). Particularly in damp indoor environments the mould genera mostly associated with the deterioration of building materials are Cladosporium, Penicillium and Aspergillus (Huang et al., 2015; Shirakawa et al., 2003; Verdier et al., 2014). The presence of these microorganisms, that are frequently isolated from indoor surface samples, independently of the technique or the type of material, can have a significant impact on indoor air quality (Verdier et al., 2014) and, therefore, innovation attempts on building materials should take into account their biological susceptibility.

Regarding factors associated with the mortar, an increased porosity reduces the strength of the mortar and increases the permeability to water vapour, resulting in a greater readiness to colonization (Giannantonio et al., 2009). However, studies performed by Shirakawa et al. (2003) and Tran et al. (2013) in blended and pure cement mortars, respectively, have shown that the porosity may have minimal effect on biological colonization. Regarding $\mathrm{pH}$, values close or higher than 10 were found to inhibit growth of Cladosporium sphaerospermum though values below or close 9 allowed the colonisation of the mortars tested (Shirakawa et al., 2003). It is also necessary to have a minimum nutrient content so that growth is stimulated (Röhlen, 2012).

Earth has been used as a building material for thousands of years (Emiroğlu et al. 2015; Niroumand et al., 2017); thus, earth buildings can be found in many parts of the world. Earth mortars are the most compatible and can be used on the repair of earthen walls. Unlike what happens with other types of mortars, such as lime or cement mortars (Santos et al., 2017), they have similar deformability and water vapour permeability. There are still few studies that evaluate the physical-mechanical characteristics of earth mortars (Delinière et al., 2014; Hamard et al., 2013; Stazi et al., 2016; Gomes et al., 2016; Pinto et al., 2017). Hence the importance of evaluating 
their characteristics, such as mechanical resistance, thermal conductivity, behaviour in contact with water, but also their susceptibility to biological contamination, since studies on that area are scarce. The influence of the formulation on the mortars characteristics and namely the addition of products such as PCM, fibres and air lime, are also considered important in order to evaluate the behaviour of each mortar and the improvement of its characteristics towards optimization.

The present research involved a ready-mixed earth plastering mortar, based on a clayish earth, sand and oat fibres, and five other mortars formulated in laboratory ranging in the particle size of sands (coarse and fine), the partial replacement of the fine sand by a PCM and the addition of low amounts of oat fibres and hydrated air lime. The mortars were prepared in controlled laboratory conditions, characterized in the fresh state and samples were produced. Several tests were performed on mortar samples to evaluate the physic-mechanical properties and biological susceptibility of the mortars. The mortars were characterized based on the test procedures described in German standard DIN 18947 (DIN, 2013). However, other standards and specific test procedures implemented by the authors, with a history of application to earth mortars (Faria et al., 2015; 2014), have been included.

This study aims to assess the influence of formulation on the properties of eco-efficient clayish earth plastering mortars. The aim is to achieve good workability and limited drying shrinkage, adequate thermal properties and mechanical behaviour but without jeopardising the need of controlled susceptibility to mould development.

\section{Materials, mortars and methods}

\subsection{Materials}

A ready-mixed earth plastering mortar (P) from Embarro Company (Portugal and Spain) with unknown formulation but based on raw clayish earth from the Algarve region (South of Portugal), similar to the clayish earth used by other authors (Faria et al., 2016; Lima et al., 2016; Lima and Faria, 2016), siliceous sand with $0-2 \mathrm{~mm}$ and cut oat fibres 1-2 $\mathrm{cm}$ long, was used as control/reference. Lima and Faria (2016) and Faria et al. (2016) used illitic clayish earths collected 
in the same clay pit of the clayish earth analysed in the present study, although in a different period and, eventually, area of the pit. Therefore, the clayish earth used is not exactly the same but there are evident similarities between them. Five other earth-based mortars were produced with a clayish earth (E) from the same region and different proportions of: two siliceous sand with different particle size distributions (a coarse sand CS and a fine sand FS); a PCM, Micronal DS $5040 \mathrm{X}$, from BASF; oat fibres cut 1-2 cm long (F) commercialized by Conlino Company and powder hydrated air lime classified as CL90 by EN 459-1 (CEN, 2010) from Lusical - Lhoist Group (CL). The clayish earth for the formulated mortars has been previously disaggregated and sieved at $2 \mathrm{~mm}$ to eliminate big clods.

\subsection{Characterization of materials}

The dry P mortar product and the raw materials of the other mortars were observed visually. The materials were characterized in terms of loose bulk density, based on EN 1097-3 (CEN, 1998a), and dry particle size distribution (dry method), based on EN 1015-1 (CEN, 1998b).

The clayish earth presented a reddish colour, similar with the colour of the fine particles of the ready-mixed product. The oat fibres could be identified in the ready-mixed product. The loose bulk density of the ready-mixed product and materials of the formulated mortars is presented in Table 1 (average value and its standard deviation). The particle size distribution (average of three samples) of the ready-mixed product and materials of the formulated mortars is shown in Figure 1.

Table 1. Loose bulk density of materials.

\begin{tabular}{lc}
\hline Mortar & $\begin{array}{c}\text { Bulk density } \\
{\left[\mathrm{kg} / \mathrm{dm}^{3}\right]}\end{array}$ \\
\hline Ready-mixed P & $1.54 \pm 0.01$ \\
Clayish earth E & $1.46 \pm 0.01$ \\
Sand FS & $1.50 \pm 0.00$ \\
Sand CS & $1.50 \pm 0.00$ \\
PCM & $1.02 \pm 0.01$ \\
Fibre F & $0.07 \pm 0.00$ \\
Air lime CL & $0.6 \pm 0.00$ \\
\hline
\end{tabular}




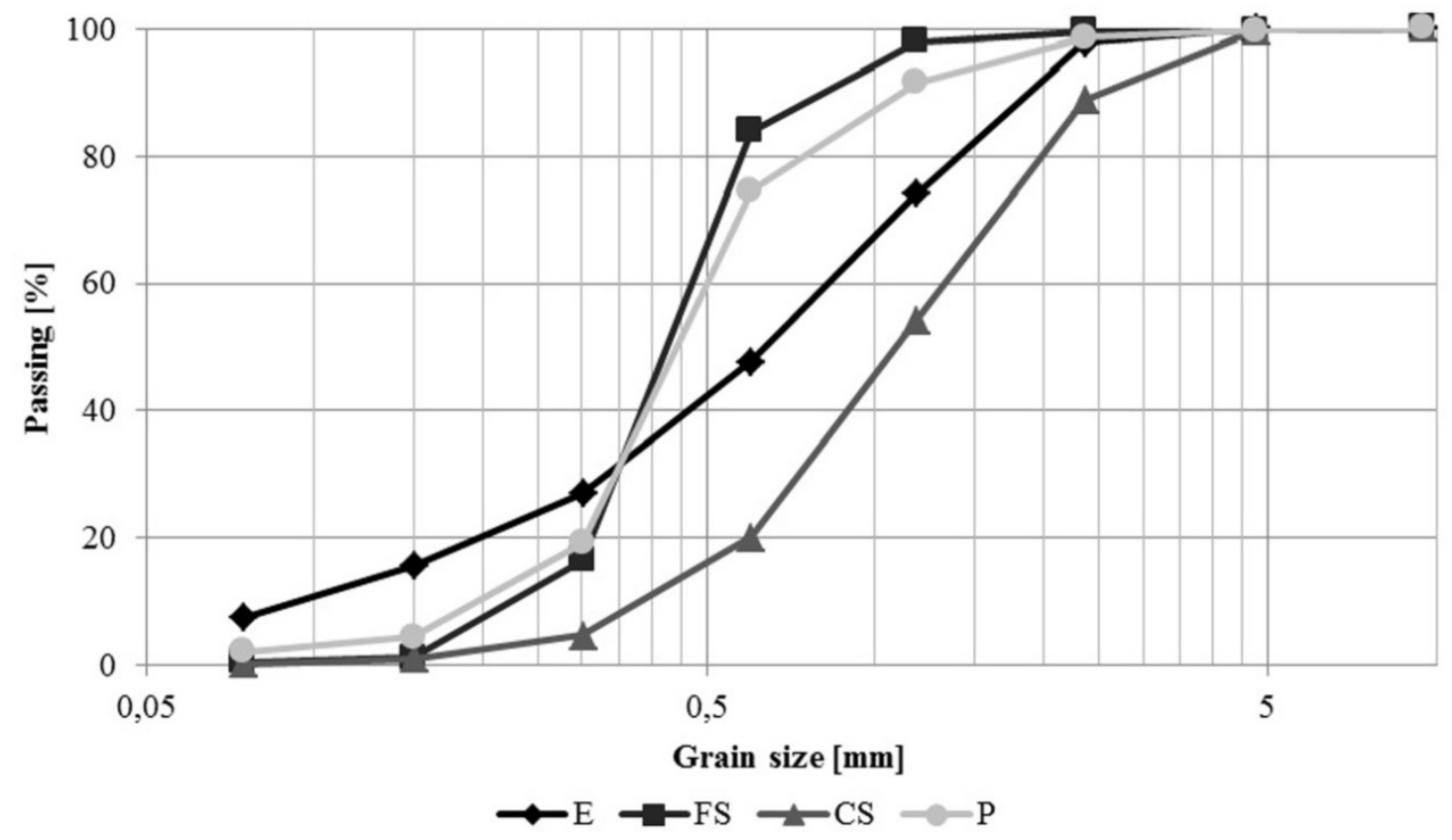

Fig. 1. Dry particle size distribution of the ready-mixed mortar product (P), fine (FS) and coarse (CS) sands and clayish earth (E).

The dry ready-mixed mortar product $(\mathrm{P})$ has higher but similar loose bulk density as the sands and the clayish earth. The bulk density of the PCM is lower but, as expected, the one of fibres is quite low in comparison with all the other materials.

The particle size distribution shows that the ready-mixed product presents a very similar result to the one of fine sand.

The mineralogical characterization of the clayish earth and dry ready-mixed mortar product (P) was carried out trough X-ray diffraction (XRD) analysis. XRD was carried out with a Phillips PW3710 X-ray diffractometer with Co K $\alpha$ radiation $(\lambda=1.7903 \AA$ ), with $35 \mathrm{kV}$ and $45 \mathrm{~mA}$, speed of $0.05 \%$ and $2 \theta$ ranging from $3^{\circ}$ to $74^{\circ}$. Two types of fractions of material were analysed: the fine fraction, obtained from the fines of material passing a $106 \mu \mathrm{m}$ sieve, which has a higher clay concentration; and the overall fraction, obtained by grinding the material to pass in $106 \mu \mathrm{m}$ sieve. Experimental peaks of diffractograms obtained in XRD analysis were compared with the peaks of the International Centre for Diffraction Data Powder Diffraction Files (ICDD PDF) database 
to identify the mineral phases. The results obtained by XRD of mortars are presented on Table 2, in qualitative terms.

Table 2. X-ray diffraction on global and fine fractions.

\begin{tabular}{lcccc}
\hline \multirow{2}{*}{\multicolumn{1}{c}{ Identified crystalline compounds }} & \multicolumn{2}{c}{ Clayish earth } & \multicolumn{2}{c}{ P mortar } \\
\cline { 2 - 5 } & $\begin{array}{l}\text { Overall } \\
\text { Fraction }\end{array}$ & $\begin{array}{c}\text { Fine } \\
\text { Fraction }\end{array}$ & $\begin{array}{c}\text { Overall } \\
\text { Fraction }\end{array}$ & $\begin{array}{c}\text { Fine } \\
\text { Fuaction }\end{array}$ \\
\hline Quartz $\left(\mathrm{SiO}_{2}\right)$ & $++/+++$ & +++ & +++ & ++ \\
Fedspar $\left(\mathrm{KAlSi}_{3} \mathrm{O}_{8}\right)$ & Vtg & $?$ & $++/+++$ & + \\
Illite $\left(\left(\mathrm{K}, \mathrm{H}_{3} \mathrm{O}\right)(\mathrm{Al}, \mathrm{Mg}, \mathrm{Fe})(\mathrm{Si}, \mathrm{Al})_{4} \mathrm{O}_{10}\left[(\mathrm{OH})_{2},\left(\mathrm{H}_{2} \mathrm{O}\right)\right]\right)$ & ++ & $+/++$ & + & ++ \\
Kaolinite $\left(\mathrm{Al}_{2} \mathrm{Si}_{2} \mathrm{O}_{5}(\mathrm{OH})_{4}\right)$ & + & + & Vtg & + \\
Hematite $\left(\mathrm{Fe}_{2} \mathrm{O}_{3}\right)$ & Vtg/+ & Vtg/+ & Vtg & Vtg/+ \\
Calcite $\left(\mathrm{CaCO}_{3}\right)$ & Vtg & $?$ & - & - \\
Dolomite $\left(\mathrm{CaMg}_{2}\left(\mathrm{CO}_{3}\right)_{2}\right)$ & ++ & $+/++$ & + & ++ \\
\hline
\end{tabular}

Peak intensity: +++ - high proportion (predominant compound); ++ - mean proportion; + - low proportion; Vtg - vestiges; ? - doubts in presence

The clayish earth is mainly illitic, although presenting some kaolinite minerals in their composition. The mortar P presents a higher proportion of feldspar and, as expected, the fine fraction presents an intensification of clay minerals (mica, kaolinite and dolomite).

Clayish illitic earths use to present a significant water vapour adsorption capacity and low swelling when wetted, promoting a reduced shrinkage (Lima et al., 2016). Considering the characteristics demonstrated by the clayish earth used in the present study, a good behaviour is expected in terms of shrinkage of these mortars.

\subsection{Production of mortars and samples}

Mortar P was the previously mentioned ready-mixed mortar. All of the mortars formulated in the laboratory had 1:3 volumetric proportions of earth and sand ( $25 \%$ of earth and $75 \%$ of sand); the sand part was differently proportioned between coarse and fine sand. Mortar with $30 \%$ of coarse sand and $45 \%$ of fine sand was considered the reference of the formulated mortars. Whenever PCM was used, it partially replaced the fine sand in percentages of $30 \%$ (volume or mass) of the total material (earth plus sand). The natural fibres and the air lime were added whenever defined. The water was added to achieve a good and similar workability of mortars (assessed by an 
experimented technician). The compositions of the mortars formulated in laboratory are presented in Table 3, in terms of volumetric and mass proportions.

Table 3. Volumetric and mass proportions of earth E, coarse and fine sands CS and FS, fibres F, PCM and air lime CL in mortars and percentage of water in function of total volume.

\begin{tabular}{|c|c|c|c|c|c|c|c|c|c|c|c|c|c|}
\hline \multirow{2}{*}{ Mortars } & \multicolumn{5}{|c|}{ Volumetric proportions } & \multicolumn{7}{|c|}{ Mass proportions } & \multirow{2}{*}{$\begin{array}{c}\text { Water } \\
{[\%]}\end{array}$} \\
\hline & $E$ & $\mathrm{CS}$ & $\mathrm{FS}$ & $\mathrm{F}$ & PCM & $\mathrm{CL}$ & $\mathrm{E}$ & $\mathrm{CS}$ & FS & $\mathrm{F}$ & PCM & $\mathrm{CL}$ & \\
\hline $\mathrm{P}$ & \multicolumn{4}{|c|}{ Unknown proportions } & - & - & \multicolumn{4}{|c|}{ Unknown proportions } & - & - & 20 \\
\hline CS30_FS45 & 1 & 1.2 & 1.8 & - & - & - & 1 & 1.23 & 1.85 & - & - & - & 20 \\
\hline CS30_FS15_PCM30 & 1 & 1.2 & 0.6 & - & 1.2 & - & 1 & 1.23 & 0.62 & - & 0.84 & - & 20 \\
\hline $\mathrm{CS} 30-\mathrm{FS} 15-\mathrm{PCM} 30+\mathrm{CL} 5$ & 1 & 1.2 & 0.6 & - & 1.2 & 0.2 & 1 & 1.23 & 0.62 & - & 0.84 & 0.08 & 20 \\
\hline CS30_FS45+F5 & 1 & 1.2 & 1.8 & 0.2 & - & - & 1 & 1.23 & 1.85 & 0.01 & - & - & 25 \\
\hline CS30_FS45+F5+CL5 & 1 & 1.2 & 1.8 & 0.2 & - & 0.2 & 1 & 1.23 & 1.85 & 0.01 & - & 0.08 & 25 \\
\hline
\end{tabular}

All the mortars were produced in the laboratory accordingly to DIN 18947 (DIN, 2013). A Controls PL5 laboratory mixing equipment was used with a low speed. The dry components were homogenized and the water was added during the first 30 seconds of mechanical mixing. After additional 30 seconds of mixing the mortar rested for 5 minutes and a last period of 30 seconds mixing completed the mortars' production.

Mechanical compaction equipment was used to prepare prismatic samples of $40 \mathrm{~mm} \times 40 \mathrm{~mm} \times$ $160 \mathrm{~mm}$ in metallic moulds with manual levelling. Manual compaction and levelling was used to prepare $20 \mathrm{~mm}$ thick smaller mortar samples applied to the back surface of glazed ceramic tiles with $40 \mathrm{~mm} \times 40 \mathrm{~mm}$ (Figure 2). 


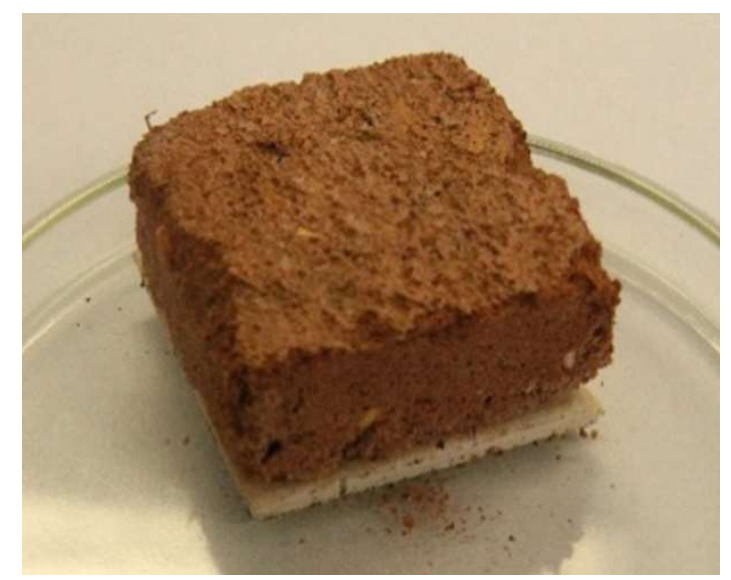

Fig. 2. Square mortar samples placed on the back of glazed ceramic tiles.

The prismatic and squared samples were de-moulded when hardened and all the samples were allowed to reach equilibrium in controlled environmental conditions at $20 \pm 2{ }^{\circ} \mathrm{C}$ and $65 \pm 5 \%$ relative humidity $(\mathrm{RH})$ for 60 days.

\subsection{Test methods}

\subsubsection{Fresh state mortars}

All mortars were characterized in the fresh state for flow table consistency, based of EN 1015-3 (CEN, 1999a), and bulk density, based on EN 1015-6 (CEN, 1999b), following DIN 18947 (DIN, 2013) procedures.

\subsubsection{Hardened mortars}

Table 4 presents a summary of the tests performed and number of samples used in each test for all hardened mortars.

Table 4. Tests performed and number of samples used per variable.

\begin{tabular}{lccccc}
\hline Test & BD, $\begin{array}{c}\text { A, Ed, FStr, } \\
\text { CStr }\end{array}$ & MIP & $\begin{array}{c}\text { Capillary } \\
\text { and } \\
\text { Drying }\end{array}$ & $\begin{array}{c}\text { Biological } \\
\text { susceptibility to } \\
\text { moulds, Sa }\end{array}$ & pH \\
\hline Sample & 3 prismatic samples & $\begin{array}{c}5 \mathrm{~cm}^{3} \text { of a } \\
\text { prismatic } \\
\text { sample }\end{array}$ & $\begin{array}{c}3 \text { cubic } \\
\text { samples }\end{array}$ & $\begin{array}{c}3 \text { samples of } \\
40 \times 40 x 20[\mathrm{~mm}]\end{array}$ & $\begin{array}{c}10 \mathrm{~g} \text { of } \\
\text { crushed } \\
\text { sample }\end{array}$ \\
\hline
\end{tabular}

Notation: BD - bulk density; $\lambda$ - thermal conductivity; Ed - dynamic modulus of elasticity; FStr, CStr - flexural and compressive strength; MIP - mercury intrusion porosimetry; Sa - surface height 


\subsubsection{Dry bulk density, microstructure and thermal conductivity}

The dry bulk density was geometrically determined according to DIN 18947 (DIN, 2013) and EN 1015-10/A1 (CEN, 1999c), by means of a digital calliper and a $0.001 \mathrm{~g}$ precision digital balance. The pore size distribution and open porosity were determined by mercury intrusion porosimetry (MIP), using a Micromeritics Autopore II mercury porosimeter and applied to a specimen taken from the prismatic samples as described elsewhere (Faria et al., 2015; Grilo et al., 2014).

Tests were performed at equilibrium with the laboratory conditions $\left(20 \pm 2^{\circ} \mathrm{C}\right.$ and $\left.65 \pm 5 \% \mathrm{RH}\right)$. An Isomet 2104 Heat Transfer Analyzer was used with a contact probe API 210412 with a 60 mm diameter. Because the samples type did not satisfy the recommendations for using the test equipment, since the surface area of the contact probe exceeded the surface area of the sample, the results obtained for the different mortars may only be compared with similar samples.

\subsubsection{Mechanical and mineralogical characterization}

The dynamic modulus of elasticity was determined based on standard EN 14146 (CEN, 2004), using a Zeus Resonance Meter ZMR 001. The flexural and compressive strengths were determined according to EN 1015-11 (CEN, 1999d), following the DIN 18947 (DIN, 2013). A Zwick Rowell Z050 equipment was used, with load cells of $2 \mathrm{kN}$ and velocity of $0.2 \mathrm{~mm} / \mathrm{min}$ for flexural test and a load cell of $50 \mathrm{kN}$ and a velocity of $0.7 \mathrm{~mm} / \mathrm{min}$ for compression test.

The mineralogical characterization of some of the earth mortars, with and without air lime, was carried out through XRD analysis, according to the test procedure defined on section 2.2 for the materials: the clayish earth $(\mathrm{E})$ and ready-mixed mortar product $(\mathrm{P})$.

\subsubsection{Capillary absorption and drying}

Capillary absorption and drying tests were carried out in a conditioned room at $20 \pm 2^{\circ} \mathrm{C}$ and 65 $\pm 5 \%$ RH. Cubic $40 \mathrm{~mm}$ samples were cut from the prismatic samples, using a handsaw, and lateral faces were waterproofed with an epoxy resin. A thin cotton cloth was placed on the bottom face of each sample, to avoid loss of fines, and was maintained by a thin elastic band. Each sample was placed inside a net basket, in order to be handled throughout the test (Faria et al., 2016). The 
capillary absorption of the mortars was assessed by sequential weighing of the cubic samples that were kept in contact with water to a height of $5 \mathrm{~mm}$ and following a general procedure based on EN 15801 (CEN, 2009) and EN 1015-18 (CEN, 2002). On current porous materials, the weighting periods should include an initial high absorption phase, an intermediate zone and a stabilization phase.

The capillary curve was plotted with water capillary absorption by contact area with water in the ordinate (in $\mathrm{kg} / \mathrm{m}^{2}$ ) and the square root of time in the abscissa (in $\mathrm{s}^{0.5}$ ).

The drying capacity of the mortars was assessed after samples had been tested for capillary for 4 hours. The test procedure described by EN 16322 (CEN, 2013) was followed. The drying curve can be plotted with time (in $\mathrm{h}$ ) in the abscissa and water content in the ordinate (in $\mathrm{kg} / \mathrm{m}^{2}$ ). This drying curve was used to calculate the drying rate of the first drying phase (DR1), by the negative slope of the initial linear section of the curve, representing the initial drying capacity of the mortar, and the drying index (DI), that represents the difficulty of achieving complete drying, in equilibrium with the environment. DI is calculated following EN 16322 (CEN, 2013) and the simplified equation presented by Grilo et al. (2014); it was determined for a period of 195 hours. The drying rate of the second drying phase (DR2) was determined with the negative slope of linear section of drying curve plotted against square root of time in the abscissa (in $\mathrm{h}^{0,5}$ ) and water content in the ordinate (in $\mathrm{kg} / \mathrm{m}^{2}$ ). Compared to the DR1 it is characterized by a decrease in liquid water transport and an increase in water vapour diffusion limited by hygric material properties (CEN, 2013).

\subsubsection{Biological susceptibility to moulds}

The biological susceptibility of the mortars to moulds was evaluated based on a previously developed method (Martins et al., 2011) adapted from ASTM D 5590-00 (reapproved 2010) (ASTM, 2010) and with Aspergillus niger van Tieghem (A. niger) used as a representative biodeterioration agent. 
Five replicates of all mortars (Figure 2) and five $45 \mathrm{~mm}$ discs of Whatman $\mathrm{n}^{\mathrm{o}} 1$ filter paper (to be used as viability controls) were steam sterilized for $20 \mathrm{~min}$ in an autoclave and then placed on the centre of pre-poured 3\% malt agar cylindrical glass flacks (approx. $500 \mathrm{ml}$ volume). A pure culture of $A$. niger from the fungal culture collection of LNEC was used to obtain a fungal suspension $\left(0.9 \times 10^{4}\right.$ spores $\left./ \mathrm{ml}\right)$ by dilution in sterile distilled water and counting in a haemacytometer. Each test sample was then inoculated by spreading evenly, with the help of a pipet, $1 \mathrm{ml}$ of the spore suspension on their surface and on the surrounding malt agar media. All flasks were incubated at $22 \pm 1{ }^{\circ} \mathrm{C}$ and $70 \pm 5 \% \mathrm{RH}$ for four weeks.

Each week and at the end of the incubation period the growth of the fungi on every test sample was rated according to the scale defined in Table 5.

Table 5. Rate of fungal (mould) development as defined in ASTM D 5590-00 (ASTM, 2010).

\begin{tabular}{ccc}
\hline Scale & Description & $\begin{array}{c}\text { Percentage of } \\
\text { contaminated }\end{array}$ \\
\hline 0 & None & $0 \%$ \\
1 & Traces of growth & $<10 \%$ \\
2 & Light growth & 10 to $30 \%$ \\
3 & Moderate growth & 30 to $60 \%$ \\
4 & Heavy growth & $>60 \%$ \\
\hline
\end{tabular}

Considering the strong influence of $\mathrm{pH}$ on mould development (Verdier et al., 2014) the $\mathrm{pH}$ of the mortars was measured: $10 \mathrm{~g}$ of crushed and milled particles of each mortar were thoroughly mixed in $100 \mathrm{~g}$ of demineralized water in glass vials, by shaking the flasks. The aqueous solutions were placed in a conditioned room at $20 \pm 2{ }^{\circ} \mathrm{C}$ and $65 \pm 5 \% \mathrm{RH}$ for 24 hours and thereafter used for measuring the $\mathrm{pH}$ with a Crison Basic $20 \mathrm{pH}$ unit, previously calibrated.

\subsubsection{Surface roughness}

The roughness test was conducted with Talysurf CLI 1000 equipment. Preliminary tests helped to define the test conditions: a resolution of $50 \mathrm{~nm}, 15 \mathrm{~mm} / \mathrm{s}$ of rate of entrainment and $500 \mathrm{~Hz}$ for 
the frequency of the beam, since it is an opaque surface. The results obtained were used by TalyMap Gold software and are defined according to ISO 25178-2 (ISO, 2012) standard.

\section{Results and discussion}

\subsection{Characterization of the fresh state mortars}

Table 6 presents the fresh state characteristics of the mortars: flow table consistency and wet density. A higher amount of water was added to both mortars formulated with fibres (CS30_FS45+F5 and CS30_FS45+F5+CL5) to assure enough workability for application, assessed by an experienced technician (Table 1). Nevertheless, the results of the flow table increased particularly for the mortar with fibres and without lime. Although the same water content was used, the addition of $5 \%$ of lime to the mortar with natural fibres led to a decrease of the flow table consistency and wet density, and it can be concluded that the lime leads to a greater absorption of water during the mixing. The partial replacement of fine sand by PCM decreased the flow and the wet density. But the addition of $5 \%$ of air lime produced a differentiated behaviour on the fresh mortars: it increases the flow and the density of mortars without fibres, while decreasing the flow of the mortars with fibres.

Table 6. Fresh mortars flow table consistency and wet density.

\begin{tabular}{lcc}
\hline Mortar & $\begin{array}{c}\text { Flow table } \\
\text { consistency } \\
{[\mathrm{mm}]}\end{array}$ & $\begin{array}{c}\text { Wet } \\
\text { density } \\
{\left[\mathrm{kg} / \mathrm{dm}^{3}\right]}\end{array}$ \\
\hline P & 161.5 & 2.00 \\
CS30_FS45 & 167.5 & 2.06 \\
CS30_FS15_PCM30 & 151.5 & 1.43 \\
CS30_FS15_PCM30+CL5 & 176.7 & 1.61 \\
CS30_FS45+F5 & 192.5 & 2.00 \\
CS30_FS45+F5+CL5 & 175.0 & 1.93 \\
\hline
\end{tabular}

All mortars have wet density higher than the minimum defined by DIN 18947 (DIN, 2013). They all show very good workability when handled but not all mortars fulfil the flow table consistency defined in that standard. Nevertheless, the main difference found on the fresh state was on the 
completely distinct workability of mortars when the PCM was added. In fact, those fresh mortars act like if an air entraining admixture has been added, with a fluffy workability that would facilitate mechanical projection application. Nevertheless, they also present a strong tendency for drying shrinkage.

Badea et al. (2016) referred that the additions of air lime in earth mortars increased the workability. In the present study, in mortars with PCM the addition of air lime increases the workability since it increases the flow table. The same is not true for mortars with addition of fibres.

Faria et al. (2016) tested a ready-mixed earth mortar produced with earth from the same region and manufacturer of the one of the present study (with $20 \%$ of water addition), and obtained 182.3 $\mathrm{mm}$ of flow table consistency and $2.11 \mathrm{~kg} / \mathrm{dm}^{3}$ of wet density. In the present study only CS30_FS45+F5 mortar presents higher flow table consistency but with high water addition. Regarding the wet density the P, CS30_FS45 and CS30_FS45+F5 mortars present similar values while the remaining mortars present lower wet density.

Sevilla Ávila et al. (2015), adding different mass percentages of a PCM (5\%, 10\% and 15\%) to a ready-mixed earth mortar, concluded that the higher the percentage of PCM, the greater the amount of water needed to guarantee the workability of the mortars. The same researchers obtained wet density of $1823 \mathrm{~kg} / \mathrm{m}^{3}$ for the ready-mixed earth mortar without the PCM and 1406$1550 \mathrm{~kg} / \mathrm{m}^{3}$ for mortars with the PCM. In the present study, where the PCM were used in percentages of $30 \%$ of the total material (much higher in comparison with the study of Sevilla Ávila et al. (2015)), the wet density is higher, except in case of CS30_FS15_PCM30 mortar.

Delinière et al. (2014) studied five earth mortars according to DIN 18947 (DIN, 2013) and, comparing with the present study, it is possible to conclude that the mortars with the same water content (20\%) present the same range of consistency $(165-182.5 \mathrm{~mm})$ and wet density $\left(2 \mathrm{~kg} / \mathrm{dm}^{3}\right)$. For earth mortars with volumetric ratio of $1: 3$ and with addition of oat straw fibres (10 and 20\%) and typha fibre-wood (20, 40 and 80\%) and with the same water content (20-25\%), Lima and 
Faria (2016) obtained consistency of 163-175 mm and wet density of $1.94-2.13 \mathrm{~kg} / \mathrm{dm}^{3}$. All tested mortars present similar consistency; the exception are P and CS30_FS15_PCM30 mortars that present lower values and with the same water content. In relation to the wet density only CS30_FS15_PCM30 and CS30_FS15_PCM30+CL5 mortars show similar results to those obtained by Lima and Faria (2016). The mortars of the present study with addition of $5 \%$ of fibres present higher consistency and comparable wet density.

Gomes et al. (2012) for kaolinitic earth mortars with 5\% of hemp fibre and 5\% of air lime addition obtained consistency of $165-172 \mathrm{~mm}$ and wet density of $1.78-1.87 \mathrm{~kg} / \mathrm{dm}^{3}$, results that are in the range of the results obtained in the present study.

\subsection{Bulk density and microstructure}

Results of bulk density determined geometrically, the classification of mortars according to DIN 18947 (DIN, 2013) and open porosity measured by MIP are presented in Table 7.

Table 7. Bulk density and standard class and open porosity of mortars.

\begin{tabular}{lccc}
\hline \multirow{2}{*}{ Mortar } & \multicolumn{2}{c}{ Bulk density $\left[\mathrm{kg} / \mathrm{dm}^{3}\right]$} & \\
\cline { 2 - 3 } & Geometric & $\begin{array}{c}\text { Class } \\
\text { PIN, 2013) }\end{array}$ & \\
\hline P & $1.77 \pm 0.00$ & 1.8 & 29.9 \\
CS30_FS45 & $1.79 \pm 0.00$ & & 28.6 \\
CS30_FS15_PCM30 & $1.27 \pm 0.04$ & 1.4 & 40.0 \\
CS30_FS15_PCM30+CL5 & $1.43 \pm 0.00$ & 1.6 & 36.2 \\
CS30_FS45+F5 & $1.72 \pm 0.02$ & 1.8 & 30.7 \\
CS30_FS45+F5+CL5 & $1.67 \pm 0.01$ & & 35.7 \\
\hline
\end{tabular}

The mortars with PCM have significantly lower bulk density and, therefore, are classified in classes 1.4 and 1.6, respectively, while all the others belong to class 1.8 .

It is possible to conclude that the addition of PCM and natural fibres on earth mortars decreases its bulk density and increases its porosity. The increase on the porosity of the mortars with addition of natural fibres may be associated with the wettability of the fibres during the mixing of mortars, which increases their volume when wetted and returns to the initial volume after drying (Laborel- 
Préneron et al., 2016). In all the cases the fibres always occupy some volume, no longer occupied by the mortar paste itself. In mortars with PCM this increase of porosity may be associated with a possible air entraining effect that the PCM introduces on mortars, already mentioned in the characterization of the mortars in the fresh state. The addition of air lime seems to attenuate these effects.

Lima and Faria (2016) obtained bulk density of 1.66-1.91 kg/ $\mathrm{dm}^{3}$ for earth mortars with straw and typha with similar water content. The mortars of the present study have similar bulk density, except the mortars with PCM, that present lower values.

Faria et al. (2016) analysed a ready-mixed earth mortar and obtained a bulk density of 1.77 $\mathrm{kg} / \mathrm{dm}^{3}$; in the present study only mortars with PCM and lime have lower values.

Palumbo et al. (2016) obtained apparent density of $0.95-1.85 \mathrm{~kg} / \mathrm{dm}^{3}$, for earth mortars with addition of different percentages of fibres. In the present study, all mortars analysed are within the range of values obtained by Palumbo et al. (2016).

Wang et al. (2016) tested the influence of PCM on clay geopolymer mortars and obtained bulk density of $1.645-1.678 \mathrm{~kg} / \mathrm{dm} 3$. In the present study, the mortars with PCM present lower bulk density in comparison with the range of Wang et al. (2016).

According to Röhlen and Ziegert (2011) earth mortars usually have open porosity of $20-30 \%$. The majority of the mortars of the present study present open porosity within this range - except mortars with PCM or air lime and fibres, which are more porous.

Incremental mercury porosimetry curves are plotted in Figure 3 (total range and zoom for 0.1-10 $\mu \mathrm{m})$. 


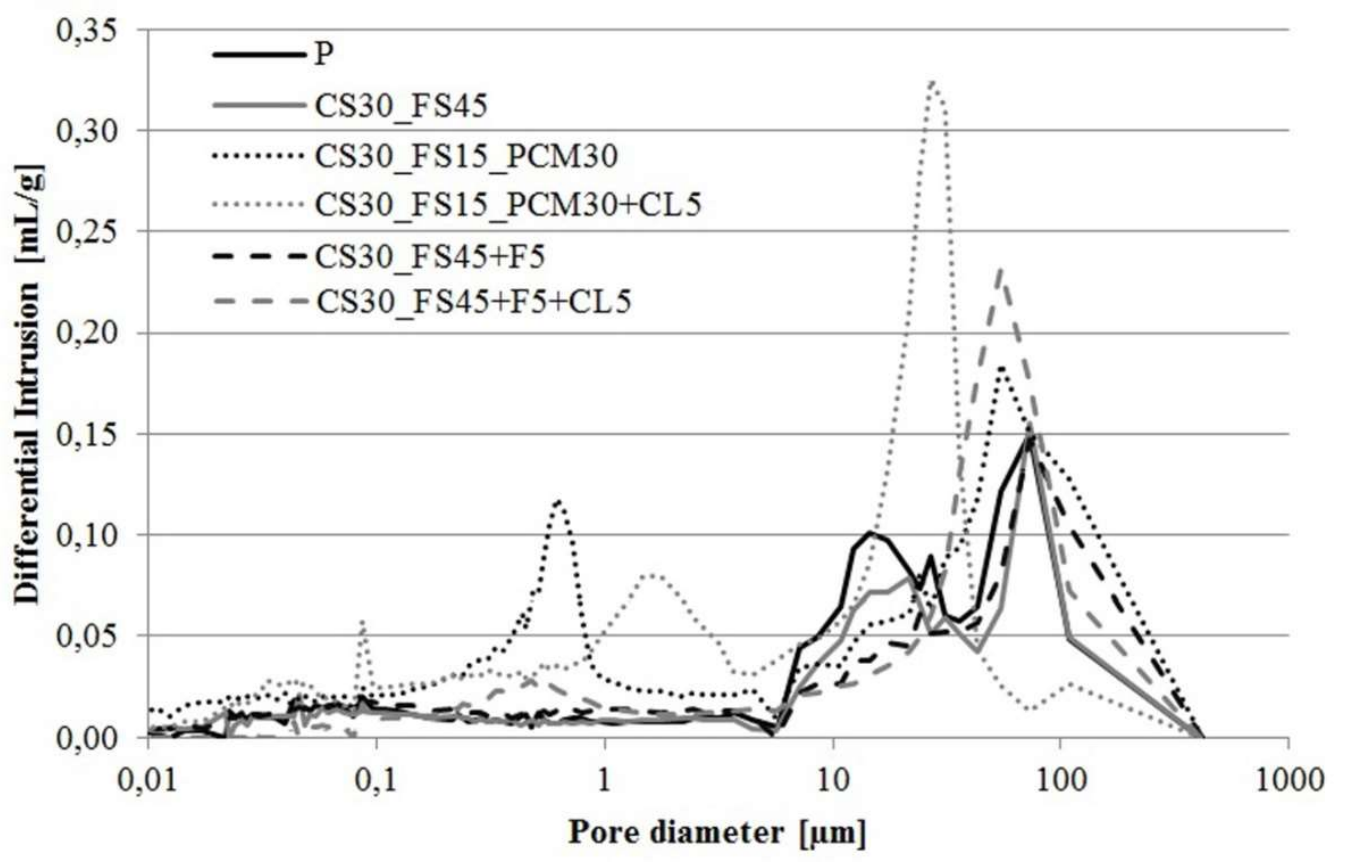

a)

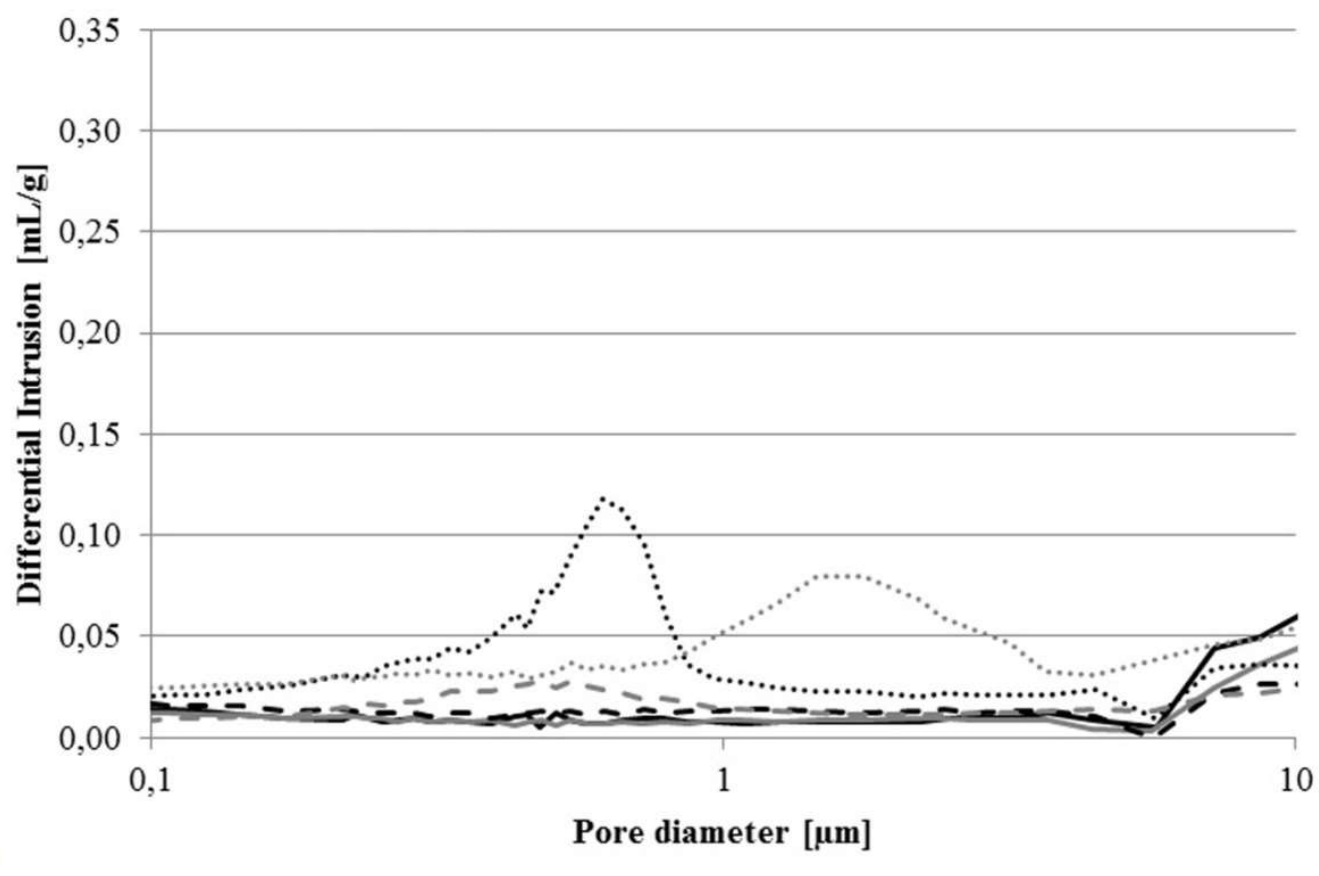

Fig. 3. Incremental mercury porosimetry curves: a) total range; b) range 0.1-10 $\mu \mathrm{m}$.

All tested mortars exhibit a bi-modal microstructure (Figure 3a). In mortars without air lime or PCM (P, CS30_FS45 and CS30_FS45+F5) this bi-modal microstructure appears to pore diameter between $14 \mu \mathrm{m}$ and $72.5 \mu \mathrm{m}$ (for differential mercury intrusion of approximately $0.04 \mathrm{ml} / \mathrm{g}$ and $0.16 \mathrm{ml} / \mathrm{g}$ ), while for the remaining mortars these dominant pore diameters appear between 0.6 $\mu \mathrm{m}$ and $54.5 \mu \mathrm{m}$ (for differential mercury intrusion of approximately $0.02 \mathrm{ml} / \mathrm{g}$ and $0.35 \mathrm{ml} / \mathrm{g}$ ). Mortars P, CS30_FS45 and CS30_FS45+F5 present similar porosimetric microstructure. 
Therefore, it is possible to conclude that the addition of the natural fibres does not alter significantly the porosimetric microstructure of mortars. The CS30_FS45+F5 mortar presents a larger number of pores of dimensions $0.1-10 \mu \mathrm{m}$, which may justify the increase of the porosity of this mortar in relation to the mortar without addition of fibres.

Mortars with PCM or air lime behave differently, with higher quantity of pores. The mortar CS30_FS15_PCM30+CL5 presents greater pore diameter (approximately $27.1 \mu \mathrm{m}$ ) and greater differential mercury intrusion (approximately $0.33 \mathrm{ml} / \mathrm{g}$ ). The addition of PCM and air lime causes a peak of pores with diameter between $0.5 \mu \mathrm{m}$ and $1.8 \mu \mathrm{m}$. In this range, the mortars with PCM exhibit most frequent pore diameter of approximately $0.6 \mu \mathrm{m}$ and differential mercury intrusion of approximately $0.12 \mathrm{ml} / \mathrm{g}$. The alteration of the porosimetric microstructure of the mortar with PCM and/or air lime (CS30_FS15_PCM30, CS30_FS15_PCM30+CL5 and CS30_FS45+F5+CL5 mortars) justifies the increase of the porosity of these mortars.

It is possible to compare the microstructure of the tested mortars with the one of another readymixed earth mortar produced by the same company and analysed by Faria et al. (2016). This one presented most frequent pore diameters at around $14 \mu \mathrm{m}$ and $55 \mu \mathrm{m}$, with $0.12 \mathrm{ml} / \mathrm{g}$ and $0.18 \mathrm{ml} / \mathrm{g}$ respectively. The ready-mixed mortar $\mathrm{P}$ of the present study shows a similar behaviour.

\subsection{Thermal conductivity}

The results of thermal conductivity for each mortar (average and standard deviation) are presented in Figure 4. The mortars with PCM show the lowest thermal conductivities.

The addition of natural fibres in earth mortars decrease the dry bulk density and porosity, which consequently decreases the thermal conductivity, confirming previous studies (Laborel-Préneron et al., 2016; Lima and Faria, 2016). In fact, this decrease in thermal conductivity associated to the decrease of dry bulk density and to the increase of porosity (Figure 4) is verified in the mortars with addition of fibres (P, CS30_FS45+F5 and CS30_FS45+F5+CL5). In the present study, the mortars with PCM present the same behaviour (decrease of thermal conductivity and dry bulk density and increase of porosity) observed in mortars with fibres. 

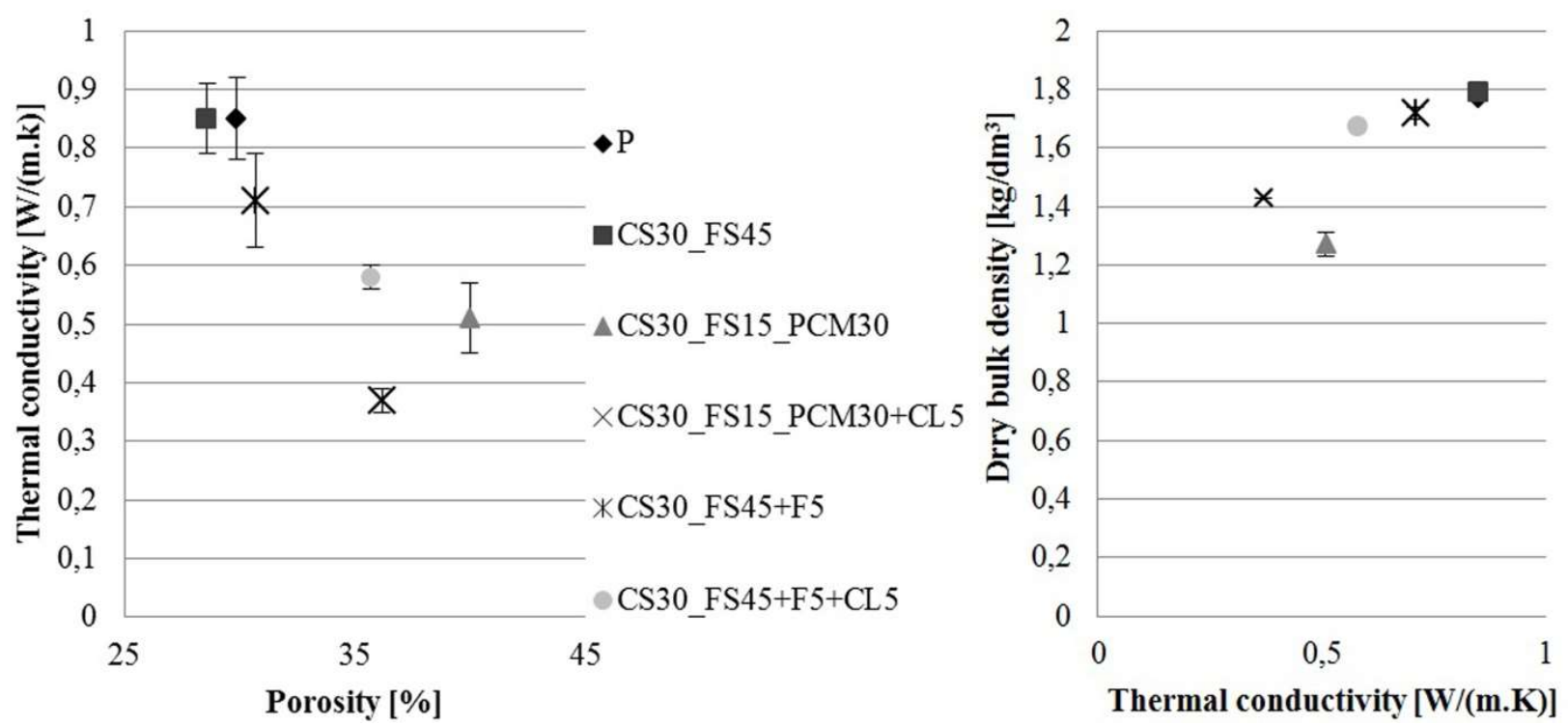

Fig. 4. Thermal conductivity of the mortars in function of porosity (left) and dry bulk density of the mortars in function of thermal conductivity (right).

Faria et al. (2016) analysed a ready-mixed earth mortar with the same test method and type of samples and obtained $0.9 \mathrm{~W} /(\mathrm{m} . \mathrm{K})$ of thermal conductivity. Mortars P and CS30_FS45 have similar thermal conductivity as the mortar tested in that study (Faria et al., 2016), while the remaining mortars present lower values.

Faria et al. (2013) analysed air lime-based mortars with washed siliceous sands with a volumetric proportion of 1:2 (air lime: sand) and mortars with partial replacement of air lime by $10 \%$ and $25 \%$ of a kaolinitic earth (by volume). The researchers discussed the thermal conductivity of mortars using the same type of test probe and samples that were used in the present study. For the air lime-based mortars the thermal conductivity decreased with the replacement of air lime by earth, whereas in the present study it decreases with the addition of $5 \%$ of air lime on earth mortars with fibres.

For earth mortars Lima and Faria (2016) obtained thermal conductivity of $0.99-1.45 \mathrm{~W} /(\mathrm{m} . \mathrm{K})$, which are higher than those obtained by the mortars analysed in the present study.

Palumbo et al. (2016) analysed a commercial earth mortar, with a kaolinitic clayish earth, without and with addition of $1 \%$ or $2 \%$ of different fibres (barley straw, barley wool and corn pith), with variable water content addition (between $17-57 \%$ per dry mass) and evaluated the thermal 
conductivity of these mortars using a transient electronic thermal analyser Quickline-30, with samples of $100 \mathrm{~mm}$ of diameter and $20 \mathrm{~mm}$ of thickness. These researchers obtained thermal conductivity of $0.3-1.4 \mathrm{~W} /(\mathrm{m} . \mathrm{K})$. The values obtained in the present study are within the range of values obtained by Palumbo et al. (2016).

For three commercially clay-based plasters, with cereal straw, and an earth mortar with a natural and unprocessed earth, Randazzo et al. (2016) obtained thermal conductivity of 0.77-1.16 $\mathrm{W} /(\mathrm{m} . \mathrm{K})$ for $100^{\circ} \mathrm{C}$ and of $0.74-1.08 \mathrm{~W} /(\mathrm{m} . \mathrm{K})$ for $120^{\circ} \mathrm{C}$, for mortar without fibres, and of $1.0-$ $1.17 \mathrm{~W} /(\mathrm{m} . \mathrm{K})$ for $100^{\circ} \mathrm{C}$ and of $0.91-1.23 \mathrm{~W} /(\mathrm{m} . \mathrm{K})$ for $120^{\circ} \mathrm{C}$, for mortars with fibres, analysed through circular samples of $30 \mathrm{~mm}$ of diameter and 8-12 $\mathrm{mm}$ of thickness. Values were obtained by determining the temperature of a thermocouple installed on a heated brass disk with a thermostat that was placed on the bottom of the circular samples (Randazzo et al., 2016). All earth-based mortars analysed in the present study presents lower thermal conductivity in comparison with Randazzo et al. (2016), which may be justified by the difference in fibres content (not known), the type of samples and the type of test carried out.

For ready-mixed earth mortars with an illitic-kaolinitic clay with addition of PCM, Sevilla Ávila et al. (2015) obtained thermal conductivity of $0.24-0.46 \mathrm{~W} /(\mathrm{m} . \mathrm{K})$, by ITQUIMA method (not described by the researchers). These results are lower than those obtained in the present study but the test procedure could not be compared.

Although for clay geopolymer mortars, Wang et al. (2016) analysed the influence of PCM replacing 30\% (in volume) of sand by PCM. These researches obtained a thermal conductivity of 0.46-0.62 W/(m.K). In the present study, the mortar with PCM and air lime presents a lower thermal conductivity while the P, CS30_FS45 and CS30_FS45+F5 mortars present higher thermal conductivities.

\subsection{Mechanical and mineralogical characterization}

The dynamic modulus of elasticity, flexural and compressive strengths of the mortars are presented on Table 8, in terms of average and standard deviation. 
Table 8. Dynamic modulus of elasticity Ed, flexural and compressive strength FStr and CStr.

\begin{tabular}{lccc}
\hline Mortar & $\begin{array}{c}\text { Ed } \\
{\left[\mathrm{N} / \mathrm{mm}^{2}\right]}\end{array}$ & $\begin{array}{c}\text { FStr } \\
{\left[\mathrm{N} / \mathrm{mm}^{2}\right]}\end{array}$ & $\begin{array}{c}\text { CStr } \\
{\left[\mathrm{N} / \mathrm{mm}^{2}\right]}\end{array}$ \\
\hline P & $4331 \pm 25$ & $0.24 \pm 0.00$ & $0.55 \pm 0.02$ \\
CS30_FS45 & $3933 \pm 161$ & $0.22 \pm 0.01$ & $0.56 \pm 0.05$ \\
CS30_FS15_PCM30 & $370 \pm 48$ & $0.09 \pm 0.04$ & $0.42 \pm 0.05$ \\
CS30_FS15_PCM30+CL5 & $1182 \pm 12$ & $0.03 \pm 0.00$ & $0.20 \pm 0.01$ \\
CS30_FS45+F5 & $3838 \pm 57$ & $0.19 \pm 0.02$ & $0.43 \pm 0.10$ \\
CS30_FS45+F5+CL5 & $1577 \pm 70$ & $0.09 \pm 0.02$ & $0.22 \pm 0.04$ \\
\hline
\end{tabular}

The mortars CS30_FS45 and CS30_FS45+F5, without PCM or air lime, present mechanical properties that are comparable with the ready-mixed mortar P. The mortars CS30_FS15_PCM30, CS30_FS15_PCM30+CL5 and CS30_FS45+F5+CL5 have higher porosity and higher amount of large pores; that can justify the low strength of these mortars. It can also be observed that the addition of air lime to mortars with PCM or with fibres clearly decreases the flexural and compressive strength of mortars. Therefore, it seems that the addition of a low amount of air lime is not beneficial for the mechanical behaviour of these earth-based mortars, most probably by discontinuing the bond between the lamellar clay particles and without a strong enough chemical carbonation reaction to compensate it.

In some cases in the literature, the addition of natural fibres to earth mortars promoted an increase of the compressive strength (Palumbo et al., 2016). This is not observed in the present study, in which the addition of fibres to earth mortars decreases their compressive strength. This loss of compressive strength can be justified by the increase of the kneading water for mixing these mortars, promoting an increase of the porosity of the mortars and, consequently, a loss of strength. Nevertheless, simple formulated earth mortars, with a clayish earth, sand and fibres, typically meet the requirements for mechanical performance of plastering mortars for old masonry but also for current new masonry, because a minimum of $0.4 \mathrm{MPa}$ is achieved for compressive strength (CEN, 2016). For all the tested mortars, only those with air lime do not accomplish this limit.

Figure 5 presents the diffractograms of the global fraction of CS30_FS45+F5 and CS30_FS45+F5+CL5 mortars with the indication of crystalline phase identified. 


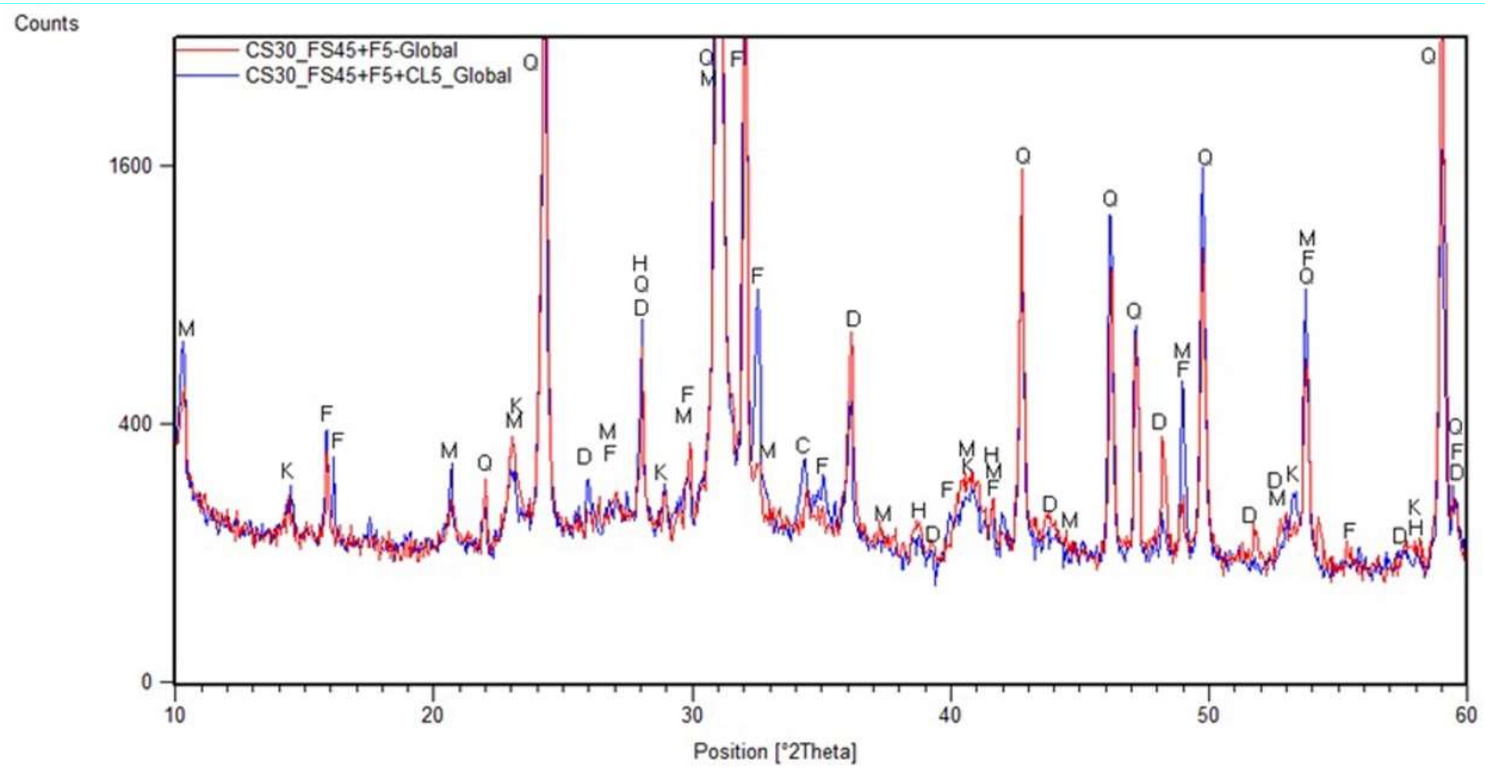

Notation: D - Dolomite; F - Feldspar; H - Hematite; K - Kaolinite; M - Mica; Q - Quartz; C - Calcite

Fig. 5. XRD diffractograms of global fraction of CS30_FS45+F5 and CS30_FS45+F5+CL5 mortars.

The addition of a low amount of air lime to the earth mortar promotes the appearance of calcite minerals. However, the occurrence of a chemical reaction in this mortar is not observed. This fact justifies the loss of mechanical resistance in the mortars with the addition of air lime in comparison to the same mortars but without that addition.

Rato (2006) stated that, in mortars with current binders, mechanical strength decreases with particle size distribution of sand. Mortar CS30_FS15_PCM30 has finer aggregate due to PCM replacement and low mechanical strength, what follows the thesis of Rato (2006). When comparing mortars CS30_FS15_PCM30+CL5 with CS30_FS45+F5+CL5, both having the same air lime addition, the strength presented by the mortar with finer aggregate (with PCM) is also lower.

In relation to dynamic modulus of elasticity, Röhlen and Ziegert (2011) defined a large range of $450-3000 \mathrm{~N} / \mathrm{mm}^{2}$. Even the tested mortars with addition of air lime fulfil this range. The mortar CS30_FS15_PCM30 is the only that does not meet this range; such a low Ed may be justified by micro-cracking that may have occurred. 
Mortars characterized by Delinière et al. (2014) obtained for flexural strength 0.49-0.69 MPa and for compressive strength 1.3-2.1 MPa. All the mortars analysed in the present study have lower strength, in comparison with Delinière et al. (2014) mortars.

In comparison with the ready-mixed mortar characterized by Faria et al. $(2016 ; 2014)$ it can be noticed that mortars with PCM and air lime, tested in the present study, have lower dynamic modulus of elasticity, while the other mortars present higher values. But in terms of flexural and compressive strength, the mortars under study are less resistant.

For earth mortars with different percentage of different fibres Lima and Faria (2016) obtained flexural strength of $0.20-0.31 \mathrm{~N} / \mathrm{mm}^{2}$ and compressive strength of $0.55-1.02 \mathrm{~N} / \mathrm{mm}^{2}$. The mortars P and CS30_FS45 present values within the range obtained by Lima and Faria (2016), while CS30_FS45+F5 and CS30_FS45+F5+CL5 mortars present lower values.

Sevilla Ávila et al. (2015), for the ready-mixed earth mortars, with a clay illitic-kaolinitic, without and with addition of different percentages of PCM, obtained flexural strengths of $0.69 \mathrm{~N} / \mathrm{mm}^{2}$ and $0.38-0.52 \mathrm{~N} / \mathrm{mm}^{2}$, and compressive strengths of $1.76 \mathrm{~N} / \mathrm{mm}^{2}$ and $0.82-0.95 \mathrm{~N} / \mathrm{mm}^{2}$, respectively for mortars without and with addition of PCM. In the present study, the values are lower. This may be due to the fact that Sevilla Ávila et al. (2015) used PCM as an addition (in percentages of 5,10 and $15 \%$ ) by weight in relation to the amount of ready-mixed mortar and not partially replacing the fine sand, as in the present study. On the other hand, the PCM contents used by Sevilla Ávila et al. (2015) were lower in comparison with the PCM mortars analyzed.

Gomes et al. (2012) for kaolinitic earth mortars with addition of 5\% of hemp fibres and 5\% of air lime obtained dynamic modulus of elasticity of 532-1065 MPa, flexural strength of $0.06-0.17 \mathrm{MPa}$ and compressive strength of 0.11-0.51 MPa. Mortar CS30_FS15_PCM30 has lower mechanical strength in comparison with these researchers, while the other mortars have higher values - except the mortars CS30_FS45+F5 and CS30_FS45+F5+CL5 which have lower compressive strength and the mortar CS30_FS45_PCM30+F5, with lower flexural strength. 
Comparing the mechanical properties obtained in the present study with the range established by Veiga et al. (2010) for plastering mortars to assure compatibility with historic masonry, it is possible to conclude that the mortars with PCM and air lime do not meet requirements for dynamic elasticity modulus and flexural strength defined by the researchers, while mortars with addition of air lime do not meet the compressive strength requirements. All the other tested mortars comply with the range defined for plasters for historic masonry (Veiga et al., 2010).

\subsection{Capillary absorption and drying}

The capillary curves of the mortars are presented in Figure 6. The test stopped when the saturation was achieved or the samples were getting degraded.

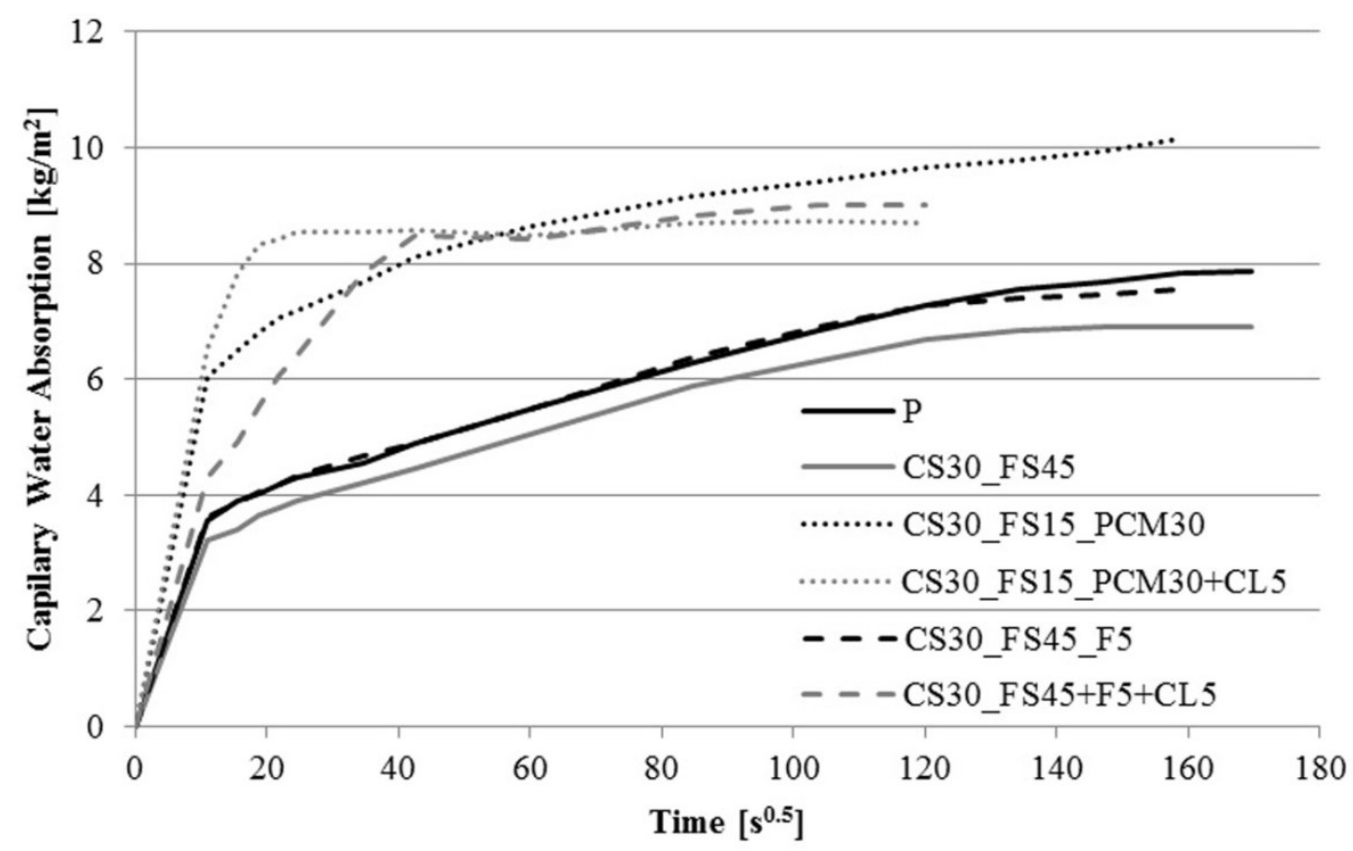

Fig. 6. Capillary curves of mortars.

Except for the mortar with PCM and air lime (CS30_FS15_PCM30+CL5), the slope of the initial segment does not represent exactly the capillary coefficient of mortars, as it can be seen by the curves. In fact, when the mortar samples were weighted after 2 minutes in contact with water $(\sim 11$ $\mathrm{S}^{0.5}$ ), some were already in the intermediate zone of the capillary curve and, for that reason, it was no longer possible to assess the most representative segment of initial absorption of those mortars. Therefore, and although in some studies that is not taken in consideration, that foreclosed an exact 
determination of the capillary coefficient for all the other mortars. Nevertheless, the observation of the capillary curve of mortars shows that all the mortars have a high capillary coefficient. Capillary coefficient of mortar CS30_FS15_PCM30+CL5 is $0.40 \mathrm{~kg} / \mathrm{m}^{2} . \mathrm{s}^{0.5}$. By observation of Figure 6 it is probable that the capillary coefficient of the mortar with PCM and without lime is higher than the previous. For mortars without PCM or air lime a very high capillary coefficient can also be foreseen. Figure 6 also shows that mortars with air lime, with or without PCM (CS30_FS15_PCM30+CL5, CS30_FS45+F5+CL5), rapidly achieve capillary saturation, in the capillary stabilization phase, in comparison with mortars without lime, with slower progression of the capillary absorption. The mortar CS30_FS15_PCM30 seems to have the most negative behaviour in terms of capillary absorption: a very high capillary coefficient and a continuous absorption increase, at least until the test was stopped.

For the evaluation of capillary absorption it is important to analyse the pores in the range of 0.1 to $10 \mu \mathrm{m}$ (Rato, 2006), which present higher capillary pressure and, consequently, greater capillary absorption. By observing the capillarity curve obtained by the mortars analysed in the present study it is possible to observe that mortars with higher capillary absorption are mortars with addition of PCM and air lime and fibres (CS30_FS15_PCM30, CS30_PCM30+CL5 and CS30_FS45+F5). This increase in capillary absorption can be justified by the greater occurrence of smaller pores $(0.1-10 \mu \mathrm{m})$ in these mortars, as evidenced by the analysis of their porosimetric microstructure.

The ready-mixed earth mortar analysed by Faria et al. (2016) with the same type of samples, waterproofed and tested according the same standards EN 15801 (CEN, 2009) and EN 1015-18 $(\mathrm{CEN}, 2002)$ obtained a capillary coefficient of $0.5 \mathrm{~kg} / \mathrm{m}^{2} \cdot \mathrm{min}^{0.5}$. The capillary coefficient obtained by these researchers is higher than the value obtained in the present study for CS30_FS15_PCM30+CL5 mortar.

Gomes et al. (2016; 2012) studied earth mortars with a kaolinitic clay and additions of hemp fibres and air lime. These researchers analysed the mortars according the same standard (EN 15801 
(CEN, 2009)) but using cubic samples with $50 \mathrm{~mm}$ and obtained capillary coefficient of 0.14 $\mathrm{kg} / \mathrm{m}^{2} . \mathrm{s}^{0.5}$ (Gomes et al., 2012) and $0.12 \mathrm{~kg} / \mathrm{m}^{2} . \mathrm{s}^{0.5}$ (Gomes et al., 2015) for mortars without additions and $0.22-0.23 \mathrm{~kg} / \mathrm{m}^{2} . \mathrm{s}^{0.5}$ for mortar with addition of $5 \%$ of air lime (Gomes et al., 2015; 2012). The mortar with 5\% of air lime (CS30_FS15_PCM30+CL5) of the present study has a higher capillary coefficient.

Figure 7 presented the drying curve of the mortars with time in abscissa. The segments of initial drying determine the drying rate of drying phase 1 (DR1). A higher slope of the curve with respect to the horizontal axis reflects a high drying rate and faster initial drying.

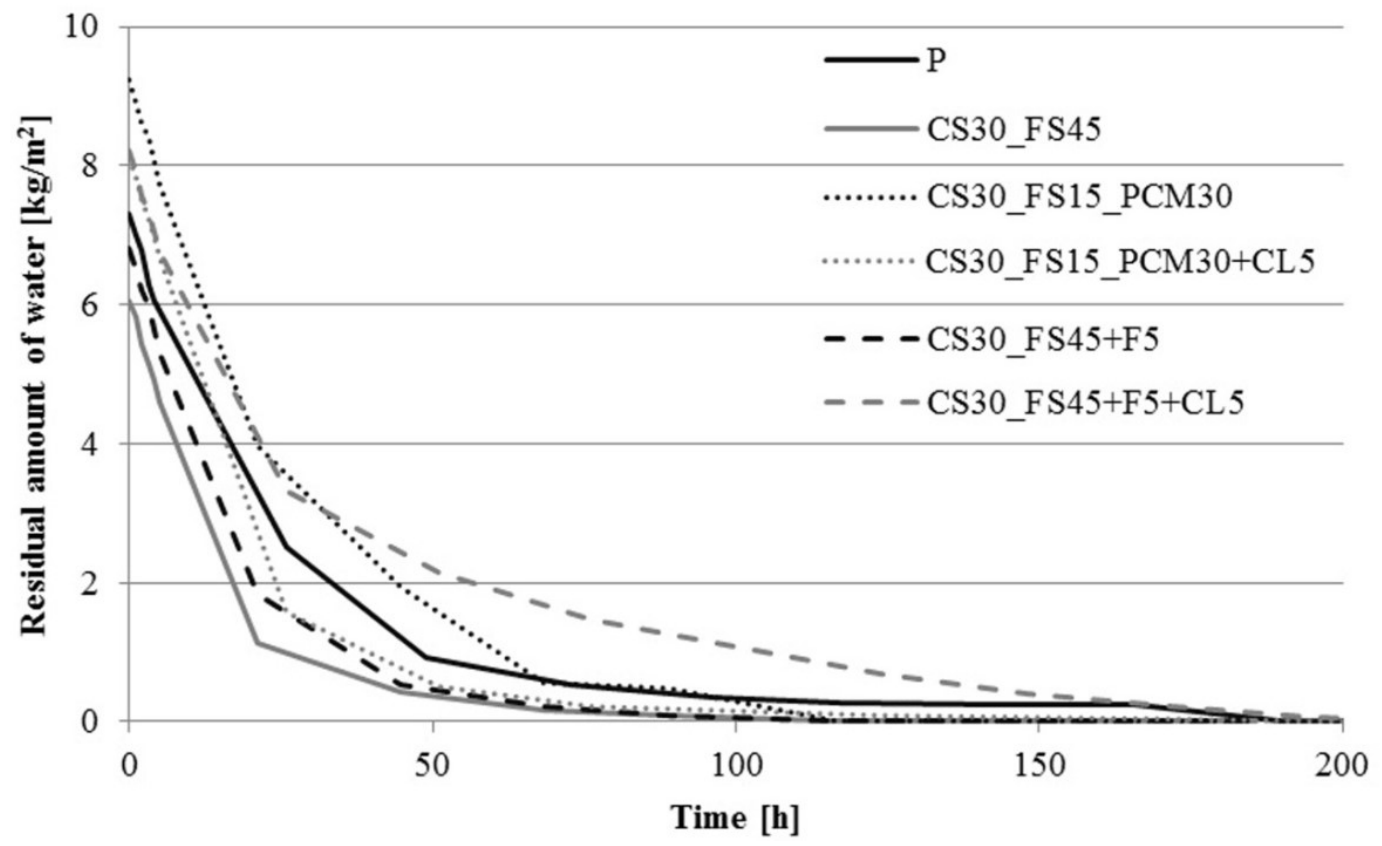

Fig. 7. Drying curves of mortars by time.

Table 9 presents the drying rate of phases 1 and 2 and the drying index, in terms of average and standard deviation. A lower DI expresses a better capacity for total drying.

Table 9. Drying rates of phases 1 and 2 and drying index of the mortars.

\begin{tabular}{cccc}
\hline Mortar & $\begin{array}{c}\text { DR1 } \\
{\left[\mathrm{kg} /\left(\mathrm{m}^{2} \cdot \mathrm{h}\right)\right]}\end{array}$ & $\begin{array}{c}\text { DR2 } \\
{\left[\mathrm{kg} /\left(\mathrm{m}^{2} \cdot \mathrm{h}^{0.5}\right)\right]}\end{array}$ & $\begin{array}{c}\text { DI } \\
{[-]}\end{array}$ \\
\hline 27 &
\end{tabular}




\begin{tabular}{lccc}
\hline P & $0.18 \pm 0.02$ & $1.06 \pm 0.05$ & $0.15 \pm 0.01$ \\
CS30_FS45 & $0.23 \pm 0.04$ & $1.40 \pm 0.24$ & $0.09 \pm 0.01$ \\
CS30_FS15_PCM30 & $0.25 \pm 0.06$ & $1.52 \pm 0.37$ & $0.15 \pm 0.01$ \\
CS30_FS15_PCM30+CL5 & $0.25 \pm 0.00$ & $1.67 \pm 0.02$ & $0.11 \pm 0.00$ \\
CS30_FS45+F5 & $0.23 \pm 0.01$ & $1.43 \pm 0.03$ & $0.10 \pm 0.00$ \\
CS30_FS45+F5+CL5 & $0.18 \pm 0.01$ & $1.17 \pm 0.05$ & $0.21 \pm 0.01$ \\
\hline
\end{tabular}

The formulated mortars present a faster initial drying (higher DR1), except the mortar with fibres and air lime (CS30_FS45+F5+CL5) with similar DR1 as the ready-mixed mortar. Mortars P and CS30_FS45+F5+CL5 are also the ones with slower drying in phase 2. Analysing the drying index, it is possible to conclude that the mortar with fibres and air lime (CS30_FS45+F5+CL5) is the one with more difficulty for total drying. The addition of fibres to the reference earth mortar formulation (comparison between CS30_FS45 and CS30_FS45+F5) is not significant for the drying index but with the addition of air lime (comparison with mortar CS30_FS45+F5+CL5), DI value doubled.

Therefore, the mortars that performed better in terms of capillary and drying capacities are mortars without air lime and PCM additions, including ready-mixed mortar P and particularly the formulated mortars CS30_FS45 and CS30_FS45+F5, with slow progression of the capillary absorption, adequate drying rates and low drying index. These are the formulated mortars which present the higher mechanical properties and results can be justified by microstructure.

Observing more in detail the range $0.1-10 \mu \mathrm{m}$ in Figure $3 \mathrm{~b}$, it can be noticed that the mortar CS30_FS15_PCM30 presents a peak at $0.62 \mu \mathrm{m}$ with an intrusion of $0.12 \mathrm{~mL} / \mathrm{g}$, while the mortar CS30_FS15_PCM30+CL5 presents a peak at $1.76 \mu \mathrm{m}$ with an intrusion of $0.08 \mathrm{~mL} / \mathrm{g}$. Finally, the mortar CS30_FS45+F5+CL5 features a small peak at $0.58 \mu \mathrm{m}$ with an intrusion of $0.03 \mathrm{~mL} / \mathrm{g}$ while the remaining mortars do not show any peak in this range. The increase of pores with this low capillary range may justify this negative effect in terms of capillary absorption.

Faria et al. (2016) analysed the drying of a ready-mixed earth mortar by the same standard EN $16322(\mathrm{CEN}, 2013)$ and obtained $0.3 \mathrm{~kg} /\left(\mathrm{m}^{2} . \mathrm{h}\right)$ of drying rate in the $1 \mathrm{st}$ phase and 0.15 of drying index, for a period of 137 hours. In the present study, all the mortars present a lower value of 
drying rate in the 1 st phase. For the drying index, the P and CS30_FS15_PCM30 mortars present the same values, the CS30_FS45+F5+CL5 present a higher value while the remaining mortars present lower values.

Gomes et al. (2012) determined the drying index with a different period of time than the one used in the present study and, before starting the drying test, the samples used in the present study were not totally saturated by capillarity, due to its fragility in contact with water. Comparing the drying index obtained in the present study with the one obtained by Gomes et al. (2012) - and bearing in mind that the earth used by Gomes et al (2012) was kaolinitic and hemp fibres were used - it is possible to notice that the first mentioned results are higher. It is disadvantageous and most probably may be directly connected with the type of clay of the selected raw earths.

\subsection{Biological susceptibility to moulds}

The biological susceptibility to the mould A. niger of the mortars tested was, as expected, influenced by their composition and $\mathrm{pH}$. The average results obtained are summarised in Table 10. The validity of the test was confirmed by the results of the paper control. The maximum grade of fungal growth was obtained between the second and third weeks of exposure.

Table 10. Results of $\mathrm{pH}$ measurements and susceptibility to moulds evaluation.

\begin{tabular}{lccccc}
\hline \multirow{2}{*}{ Mortar } & \multirow{2}{*}{$\mathrm{pH}$} & \multicolumn{4}{c}{ Fungal development } \\
\cline { 3 - 6 } & & Week 1 & Week 2 & Week 3 & Week 4 \\
\hline Paper control & - & $2.8 \pm 0.4$ & $3.8 \pm 0.4$ & 4.0 & 4.0 \\
Commercial mortar - P & 8.87 & $1.8 \pm 0.4$ & $1.8 \pm 0.4$ & $2.4 \pm 0.5$ & $2.6 \pm 0.5$ \\
CS30_FS45 & 8.93 & $0.6 \pm 0.5$ & $0.8 \pm 0.8$ & $1.6 \pm 1.5$ & $1.6 \pm 1.5$ \\
CS30_FS15_PCM30 & 8.53 & $1.2 \pm 0.8$ & $1.4 \pm 0.9$ & $2.2 \pm 1.3$ & $3.0 \pm 1.2$ \\
CS30_FS15_PCM30+CL5 & 9.56 & $0.2 \pm 0.4$ & $0.6 \pm 1.3$ & $0.8 \pm 1.8$ & $0.8 \pm 1.8$ \\
CS30_FS45+F5 & 8.99 & $1.4 \pm 0.5$ & $1.8 \pm 0.4$ & $2.6 \pm 0.5$ & $3.4 \pm 0.9$ \\
CS30_FS45+F5+CL5 & 9.44 & $0.6 \pm 0.5$ & $0.8 \pm 0.4$ & 1.0 & 1.0 \\
\hline
\end{tabular}

Scale: 0 - no growth; 1 - traces of growth; 2 - light growth; 3 - moderate growth; 4 - heavy growth

The addition of either PCM (CS30_FS15_PCM30) or fibres (CS30_FS45+F5) to the reference mortar (CS30_FS45) increased significantly their susceptibility to A. niger development.

Although the exact composition of the ready-mixed mortar $\mathrm{P}$ is unknown, it incorporates natural fibres but neither PCM nor air lime; therefore, can be compared to CS30_FS45+F5 made in the 
laboratory. As the ready-mixed mortar P shows a better behaviour, these results seem to indicate the need to improve the quality and optimize the quantity of the fibres for enhanced performance. All $\mathrm{pH}$ values measured lay between 8.5 and 9.6 and were not high enough to totally prevent mould development. Nevertheless, the partial replacement of fine sand by PCM reduces the mortars $\mathrm{pH}$, the addition of fibres does not introduce relevant changes, while the addition of air lime clearly increases the $\mathrm{pH}$ of mortars and this correlates to the better performance in terms of biological susceptibility of these samples. In fact, regardless of the presence of fibres or PCM the addition of air lime and the consequent rise of the $\mathrm{pH}$ prevent, though not completely, the fungal colonization and development.

Although the standard adapted (ASTM, 2010) limits comparisons to the given set of conditions of each test, hydraulic lime and cement mortars have shown in previous tests, with the same methodology, average results after four weeks of exposure of $0.8 \pm 0.5$ (Teixeira et al., 2014) and $2.2 \pm 0.9$ (Martins, 2010), respectively.

\subsection{Surface roughness}

The average and standard deviation of surface height, Sa, of the mortars are presented on Table 11.

Table 11. Average and standard deviation of surface height $(\mathrm{Sa})$ of mortars.

\begin{tabular}{lc}
\hline Mortar & Sa (mm) \\
\hline P & $0.23 \pm 0.04$ \\
CS30_FS45 & $0.19 \pm 0.00$ \\
CS30_FS15_PCM30 & $0.31 \pm 0.10$ \\
CS30_FS15_PCM30+CL5 & $0.39 \pm 0.14$ \\
CS30_FS45+F5 & $0.46 \pm 0.01$ \\
CS30_FS45+F5+CL5 & $0.31 \pm 0.10$ \\
\hline
\end{tabular}

The roughness of mortars increases with the partial replacement of fine sand by PCM, the addition of fibres and air lime. The mortar CS30_FS45 presents the lower surface roughness, very close to the ready-mixed mortar. As mentioned before, during the mixing mortars with PCM seemed to have higher levels of entrained air; after hardening, some white particles of PCM were visible on 
the surface. The release of entrapped air leads to superficial bubbles that became voids after hardening of the mortars and may explain the roughness increase of mortars with PCM addition. The addition of air lime together with fibres seems to diminish the mortar roughness. The readymixed mortar $\mathrm{P}$, which also has fibres, presents a low surface roughness maybe because the fibres are better incorporated, their amount is lower or the fibres are shorter, in comparison to the formulated mortar CS30_FS45+F5. Distinct quantities of kneading water may also justify some differences.

Also noteworthy is the fact that mortars with PCM and addition of both fibres and air lime have the highest standard deviations suggesting possible variation in mixing.

Comparing the results of texture (surface high) with fungal development, a positive relation between these variables was confirmed though the effect of the additives seems more relevant than the final surface profile.

\section{Conclusions}

Although earth plasters have a long history of application, their scientific knowledge only recently gained attention. Therefore, their sustained use to repair and rehabilitate old buildings or to build new ones, in the light of present day requirements of building codes and end-users, needs a better understanding of the materials involved. Despite the growing importance that has been given to this issue internationally, earth mortars do not have yet a complete characterization and, therefore, important aspects remain to be studied about their behaviour.

Microorganisms particularly associated with high moisture indoor environments are known by causing poor indoor air quality. The activity of moulds on building materials depends on a number of factors like relative humidity and temperature but also $\mathrm{pH}$ or the physical properties of the surface. Thus, the type of building material has a significant influence on the growth of fungi. The bio-receptivity of the materials seems to have the highest influence concerning water (hygroscopic behaviour), chemical composition and $\mathrm{pH}$. As stated before, the present study aimed to assess the characteristics of diverse earth mortars, analysing them to combine improved 
hygrothermal properties with adequate mechanical behaviour but taking special consideration on the influence of some additives on the biological susceptibility. The aim is to contribute to optimized production of economic and ecological efficient earth mortars and to their increased used, instead of less eco-efficient plastering mortars.

Based on the results obtained in present study, the following conclusions can be drawn:

a. The addition of natural fibres to earth mortars contributes to a decrease of bulk density and, consequently, of porosity, thermal conductivity and capillary absorption, facilitating the total drying of mortars.

b. The thermal conductivity decreases with addition of PCM and air lime to earth mortars.

c. In contrast with the positive impact on the thermal conductivity, the addition of PCM totally changes the mortars workability, increases the capillary absorption and biosusceptibility and has also a negative impact on the mechanical properties, decreasing strength. Although not quantified, it has also a negative impact on embodied energy.

d. Adding a low content of air lime to earth mortars with natural fibres reduces significantly the $A$. niger growth due to the increase of $\mathrm{pH}$ obtained, but with negative impact in terms of capillary absorption and mechanical properties.

e. Simple formulated earth mortars, produced with a clayish earth, sand and fibres, typically meet the requirements for mechanical performance of plastering mortars for old masonry but also for common new masonry (CEN, 2016).

XRD analysis did not show any reaction products when air lime was added to the earth mortars. This could not be compared with earth mortars with other types of clay and/or contents of air lime; therefore, it may depend on several factors. The decrease on mechanical strength, when a low amount of air lime is added, is significant and it is probably due to discontinuity of the bond between the clay particles provided by the inclusion of the lime particles, not compensated by the air lime reaction by carbonation, probably due to their limited content on the mortars. The low 
mechanical strengths of mortars with PCM can be justified by the macrostructure presented by those mortars, with a high amount of visible large pores.

In previous studies PCM mortars have shown a good behaviour in terms of indoor thermal properties but, considering the present results, their use for simply formulated earth mortars is not recommended without optimization.

It is important to note that the results obtained in the present study refer to a single clayish earth, one type and percentage of air lime and PCM used. Further research is necessary to analyse the influence of mortars' composition in physical-mechanical properties and bio-susceptibility: use of other types of clayish earths; the addition of other types and percentages of air lime, PCM and natural fibres.

Nevertheless, being earth mortars produced with natural materials (clayish earth, sand, natural fibres), earth plasters have a very low embodied energy, in comparison with common plasters, made with limes or cements. Bearing in mind the properties that can be achieved formulating earth plasters, it is worthwhile to continue its study and contribute to disseminate its use.

\section{Acknowledgements}

This work was supported by Fundação para a Ciência e a Tecnologia (FCT) under DBHERITAGE project (PTDC/EPH-PAT/4684/2014). The authors also acknowledge the EMBARRO Company for supplying the majority of the mortar materials and are grateful to Antonio Santos Silva, Miguel Teixeira, Sandra Noivo, Teresa Gonçalves and Vitor Silva for the support throughout the testing campaign. The support of COST Actions FP1303 "Performance of biobased building materials" and RILEM Technical Committees TCE, "Testing and Characterisation of Earth-based building materials and elements" and HDB, "Hygrothermal behaviour and Durability of Bio-aggregate based building materials", are also acknowledged. 


\section{References}

ASTM, 2010. ASTM D5590-00/2010: Determining the resistance of paint films and related coatings to fungal defacement by accelerated four-week agar plate assay; ASTM International, Pennsylvania.

Baetens, R., Jelle, B. P., Gustavsen, A., 2010. Phase change materials for building applications: A state-of-the-art review. Energ. Buildings. 42(9), 1361-1368; doi: 10.1016/j.enbuild.2010.03.026.

Cagnon, H., Aubert, J. E., Coutand, M., Magniont, C., 2014. Hygrothermal properties of earth bricks. Energ. Buildings. 80, 208-217; doi: 10.1016/j.enbuild.2014.05.024.

CEN, 1998a. EN 1097-3: 1998. Tests for mechanical and physical properties of aggregates. Part 3: Determination of loose bulk density and voids; CEN, Brussels.

CEN, 1998b. EN 1015-1:1998/A1:2006. Methods of test for mortar for masonry. Part 1: Determination of particle size distribution (by sieve analysis); CEN, Brussels.

CEN 1999a. EN 1015-3:1999/A1:2004/A2:2006. Methods of test for mortar for masonry. Part 3:

Determination of consistence of fresh mortar (by flow table); CEN, Brussels.

CEN, 1999b. EN 1015-6:1999/A1:2006. Methods of test for mortar for masonry. Part 6:

Determination of bulk density of fresh mortar; CEN, Brussels.

CEN, 1999c. EN 1015-10:1999/A1:2006. Methods of test for mortar for masonry. Part 10:

Determination of dry bulk density of hardened mortar; CEN, Brussels.

CEN, 1999d. EN 1015-11:1999/A1:2006. Methods of test for mortar for masonry. Part 11:

Determination of flexural and compressive strength of hardened mortar; CEN, Brussels.

CEN, 2002. EN 1015-18: 2002. Methods of test for mortar for masonry. Part 18: Determination of water absorption coefficient due to capillary action of hardened mortar; CEN, Brussels.

CEN, 2004. EN 14146: 2004. Natural stone test methods. Determination of the dynamic modulus of elasticity (by measuring the fundamental resonance frequency); CEN, Brussels. 
CEN, 2009. EN 15801: 2009. Conservation of cultural property. Test methods. Determination of water absorption by capillarity; CEN, Brussels.

CEN, 2010. EN 459-1: 2010. Building lime. Part 1: Definitions, specifications and conformity criteria; CEN, Brussels.

CEN, 2013. EN 16322: 2013. Conversation of Cultural Heritage. Test methods. Determination of drying properties; CEN, Brussels.

CEN, 2016. EN 998-1: 2016. Specification for mortar for masonry. Part 1: Rendering and plastering mortar; CEN, Brussels.

Darling, E., Cros, C. J., Wargocki, P., Kolarik, J., Morrosin, G. C., Corsi, R. L., 2012. Impacts of clay plaster on indoor air quality assessed using chemical and sensory measurements. Build. Environ. 57, 370-376; doi: 10.1016/j.buildenv.2012.06.004.

Delinière, R., Aubert, J. E., Rojat, F., Gasc-Barbier, M., 2014. Physical, mineralogical and mechanical characterization of ready-mixed clay plaster. Build. Environ. 80, 11-17; doi: 10.1016/j.buildenv.2014.05.012.

DIN, 2013. DIN 18947: Earth plasters - Terms and definitions, requirements, test methods (in German); DIN, Berlin.

Eires, R., Camões, A., Jalali, S., 2017. Enhancing water resistance of earthen building with quicklime and oil. J. Clean. Prod. 142, 3281-3292; doi: 10.1016/j.jclepro.2016.10.141.

Emiroğlu, M., Yalama, A., Erdoğdu, Y., 2015. Performance of ready-mixed clay plasters produced with different clay/sand ratios. Appl. Clay Sci., 115, 221-229; doi: 10.1016/j.clay.2015.08.005.

Faria, P., Silva, V., Jamú, N., Dias, I., Gomes, I., 2013. Evaluation of air lime and clayish earth mortars for earthen wall renders, in: M. Correia, G. Carlos, S. Rocha (Eds.), Vernacular Heritage and Earthen Architecture: Contributions for Sustainable Development. CRC Press/Taylor \& Francis Group, pp. 407-413. 
Faria, P., Santos, T., Silva, V., 2014. Earth-based mortars for masonry plastering, in: 9th International Masonry Conference, Guimarães, Portugal (CD-rom).

Faria, P., Santos, T., Aubert, J. E., 2016. Experimental characterization of an earth eco-efficient plastering mortar. J. Mater. Civil Eng. 28(1), 04015085-1/9; doi: 10.1061/(ASCE)MT.1943-5533.0001363.

Giannantonio, D., Kurth, J., Kurtis, K., Sobecky, P., 2009. Effects of concrete properties and nutrients on fungal colonization and fouling. Int. Biodeter. Biodegr. 63(3), 252-259; doi: 10.1016/j.ibiod.2008.10.002.

Gomes, M. I., Gonçalves, T. D., Faria, P., 2012. Earth-based repair mortars: experimental analysis with different binders and natural fibers, in: Mileto, Vegas \& Cristini (Eds.), Rammed Earth Conservation. Taylor \& Francis, London, pp: 661-668.

Gomes, M. I., Gonçalves, T. D., Faria, P., 2016. Hydric Behavior of Earth Materials and the Effects of Their Stabilization with Cement or Lime: Study on Repair Mortars for Historical Rammed Earth Structures. J. Mater. Civil Eng. 28(7), 04016041; doi: 10.1061/(ASCE)MT.1943-5533.0001536.

Grilo, J., Faria, P., Veiga, R., Santos Silva, A., Silva, V., Velosa, A., 2014. New natural hydraulic lime mortars. Physical and microstructural properties in different curing conditions. Constr. Build. Mater. 54, 378-384; doi: 10.1016/j.conbuildmat.2013.12.078.

Hamard, E., Morel, J. C., Salgado, F., Marcom, A., Meunier, N., 2013. A procedure to assess the suitability of plaster to protect vernacular earthen architecture. J. Cult. Herit. 14(2), 109115; doi: 10.1016/j.culher.2012.04.005.

Huang, H. L., Lin, C. C., Hsu, K., 2015. Comparison of resistance improvement to fungal growth on green and conventional building materials by nano-metal impregnation. Build. Environ. 93, 119-127; doi: 10.1016/j.buildenv.2015.06.016.

ISO, 2012. ISO 25178-2: Geometrical product specification - Part 2: Terms, definitions and surface texture parameters; ISO, Geneva. 
Laborel-Préneron, A., Aubert, J. E., Magniont, Tribout, C., Bertron, A., 2016. Plant aggregates and fibers in earth construction materials: A review. Const. Build. Mater. 111, 719-734; doi: 10.1016/j.conbuildmat.2016.02.119.

Lima, J., Faria, P., 2016. Eco-efficient earthen plasters: The influence of the addition of natural fibers, in: Fangueiro R., Rana S. (Eds.), Natural Fibres: Advances in science and technology towards industrial applications. RILEM bookseries, Springer, Dordrecht, 12, pp. 315-327; doi: 10.1007/978-94-017-7515-1_24.

Lima, J., Faria, P., Santos Silva, A., 2016. Earthen plasters based on illitic soils from Barrocal region of Algarve: contributions for building performance and sustainability. Key Eng. Mat. 678, 64-77; doi: 10.4028/www.scientific.net/KEM.678.64.

Lin, C. C., Chen, W. Y., 2017. Effect of paint composition, nano-metal types and substrate on the improvement of biological resistance on paint finished building material. Build. Environ. 117, 49-59; doi: 10.1016/j.buildenv.2017.02.013.

Liuzzi, S., Stefanizzi, P., 2016. Experimental investigation on lightweight and lime stabilized earth composites. Key. Eng. Mat. 666, 31-45; doi: 10.4028/www.scientific.net/KEM.666.31.

Maddison, M., Mauring, T., Kirsimäe, K., Mander, Ü., 2009. The humidity buffer capacity of clay-sand plaster filled with phytomass from treatment wetlands. Build. Environ. 44(9), 1864-1868; doi: 10.1016/j.buildenv.2008.12.008.

Martins, M., 2010. Performance of plastering mortars with regranulated of expanded cork (in Portuguese). MSc Thesis, IST, Universidade de Lisboa, Lisbon.

Martins, M., Nunes, L., Branco, F., 2011. Plastering and rendering mortars incorporating regranulated of expanded cork to improve durability, in: Freitas, V. P., Carvalho, H., Lacasse, M. (Eds.), XII DBMC, 12th International Conference on Durability of Building Materials and Components, FEUP edições, Porto, Portugal, pp. 1361-1368. 
McGregor, F., Heath, A., Shea, A., Lawrence, M., 2014. The moisture buffering capacity of unfired clay masonry. Build. Environ. 82, 599-607; doi: 10.1016/j.buildenv.2014.09.027.

Melià, P., Ruggieri, G., Sabbadini, S., Dotelli, G., 2014. Environmental impacts of natural and conventional building materials: a case study on earth plasters. J. Clean. Prod. 80, 179186; doi: 10.1016/j.jclepro.2014.05.073.

Nielsen, K. F., Holm, G., Uttrup, L. P., Nielsen, P. A., 2004. Moulds growth on building materials under low water activities. Influence of humidity and temperature on fungal growth and secondary metabolism. Int. Biodeter. Biodegr. 54(4), 325-336; doi: 10.1016/j.ibiod.2004.05.002.

Niroumand, H., Kibert, C. J., Barcelo, J. A., Saaly, M., 2017. Contribution of national guidelines in industry growth of earth architecture and earth buildings as a vernacular architecture. Renew. Sust. Energ. Rev. 74, 1108-1118, doi: 10.1016/j.rser.2017.02.074.

Palumbo, M., McGregor, F., Heath, A., Walker, P., 2016. The influence of two crop by-products on the hygrothermal properties of earth plasters. Build. Environ. 105, 245-252; doi: 10.1016/j.buildenv.2016.06.004.

Pinto, J., Cunha, S., Soares, N., Soares, E., Cunha, V. M. C. F., Ferreira, D., Sá, A. B., 2017. Earth-based render of tabique walls - An experimental work contribution. Int. J. Archit. Herit. 11(2), 185-197; doi: 10.1080/15583058.2015.1020459.

Randazzo, L., Montana, G., Hein, A., Castiglia, A., Rodonò, G., Donato, D. I., 2016. Moisture absorption, thermal conductivity and noise mitigation of clay based plasters: The influence of mineralogical and textural characteristics. Appl. Clay Sci. 132-133, 498507, doi: 10.1016/j.clay.2016.07.021.

Rato, V., 2006. Influence of morphological microstructure on mortar behaviour (in Portuguese). PhD thesis, NOVA University of Lisbon, Lisbon.

Röhlen, U., 2012. Mould on clay renders, in: 6th International Conference on Building with Earth, LEHM 2012, Dachverband Lehm e.V., pp. 113-121. 
Röhlen, U., Ziegert, C., 2011. Earth building practice. Bauwerk, Beuth Verlag GmbH, Berlin; ISBN: 978-3-410-21737-4.

Santos, T., Faria, P., Santos Silva, A., 2017. In situ evaluation of the behaviour of earth-based mortar renders with low addition of limes (in Portuguese). Conservar Património, In press; doi: 10.14568/cp2016022.

Sevilla Ávila, I., Serrano Cantó, J. L., Rodríguez, J. F., Castilla Pascual, F. J., Carmona, M., Sanz Martínez, D., 2015. Estudio metodológico sobre aprovechamento de materiales de cambio de fase para la elaboración de morteros de revestimento de arcilla en paramentos interiores de edificación, in: Arquitectura en tierra, Patrimonio Cultural, XII CIATTI, Congresso de arquitectura en tierra en Cuenca de Campos, Catedral Juan de Villanueva, Universidad de Valladolid, pp.175-186 (on-line).

Shirakawa, M. A., Beech, I. B., Tapper, R., Cincotto, M. A., Gambale, W., 2003. The development of a method to evaluate bioreceptivity of indoor mortar plastering to fungal growth. Int. Biodeter. Biodegr. 51, 83-92; doi: 10.1016/S0964-8305(01)00129-9.

Stazi, F., Nacci, A., Tittarelli, F., Pasqualini, E., Munafò, P., 2016. An experimental study on earth plasters for earthen building protection: The effects of different admixtures and surface treatments. J. Cult. Herit. 17, 27-41; doi: 10.1016/j.culher.2015.07.009.

Teixeira, M., Nunes, L., Santos, P. Jamú, N., Faria, P., 2014. Rendering mortars with air lime, earth and natural fibres. Preliminary assessment of biological susceptibility (in Portuguese), in: Argamassas 2014, I Simpósio de Argamassas e Soluções Térmicas de Revestimento, Coimbra, Portugal (CD-rom).

Tran, T., Govin, A., Guyonnet, R., Grosseau, P., Lors, C., Garcia-Diaz, E., Damidot, D., Devès, O., Ruot, B., 2012. Influence of the intrinsic characteristics of mortars on biofouling by Klebsormidium flaccidum. Int. Biodeter. Biodegr. 70, 31-39; doi: 10.1016/j.ibiod.2011.10.017. 
Veiga, R., Fragata, A., Velosa, A. L., Magalhães, A. C., Margalha, G., 2010. Lime-based mortars: viability for use as substitution renders in historical buildings. Int. J. Archit. Herit. 4(2), 177-195; doi: 10.1080/15583050902914678.

Verdier, T., Coutand, M., Bertron, A., Roques, C., 2014. A review of indoor microbial growth across building materials and sampling and analysis methods. Build. Environ. 80, 136149; doi: 10.1016/j.buildenv.2014.05.030.

Viitanen, H., Vinha, J., Salminen, K., Ojanen, T., Peuhkuri, R., Paajanen, L., Lahdesmaki, K., 2010. Moisture and biodeterioration risk of building materials and structures. J. Build. Phys. 33(3), 201-224; doi: 10.1177/1744259109343511.

Wang, Z., Su, H., Zhao, S., Zhao, N., 2016. Influence of phase change material on mechanical and thermal properties of clay geopolymer mortar. Const. Build. Mater. 120, 329-334; doi: 10.1016/j.conbuildmat.2016.05.091. 